$1-1-1908$

\title{
Notes on The Habits of Mice, Moles and Shrews : a Preliminary Report
}

Fred E. Brooks

Follow this and additional works at: https://researchrepository.wvu.edu/ wv_agricultural_and_forestry_experiment_station_bulletins

\section{Digital Commons Citation}

Brooks, Fred E., "Notes on The Habits of Mice, Moles and Shrews : a Preliminary Report" (1908). West Virginia Agricultural and Forestry Experiment Station Bulletins. 113.

https://researchrepository.wvu.edu/wv_agricultural_and_forestry_experiment_station_bulletins/113 @ WVU. It has been accepted for inclusion in West Virginia Agricultural and Forestry Experiment Station Bulletins by an authorized administrator of The Research Repository @WVU. For more information, please contact ian.harmon@mail.wvu.edu. 



\section{THE REGENTS OF THE WEST VIRGINIA UNIVERSITY}

Name of Regent.

P. O. Address.

Hon. C. M. ВАвв ............................ Walls, Va. Hon. J. B. Finley .................. Parkersburg, W. Va. Hon. D. C. Galdaher................... Charleston, W. Va. Hon. E. M. Grant....................... Hon. C. E. HAWORTH .................Huntington, W. Va Hon. C. P. McNelt.................. Wheeling, W. Va. Hon. L. J. Williams.................Lewisburg, W. Va. Hon. T. P. JAcoBs................ New Martinsville, W. Va. Hon. J. R. TRotтER.................. Buckhannon, W. Va.

President of the Board of Regents.............. R. TRotTer President of the University................ B. B. Purinton Treasurer ........................... WHITEHILL Auditor ................................ White

\section{STATION STAFF}

James H. Stewart, A. M......... Director and Agriculturist Bert H. Hite, M. S.............. Vice Director and Chemist W. M. Munson, Рн. D................... Horticulturist IV. E. Rumsey, B. S. Agr................... Entomologist Horace Atwood, M. S. Agr............Assistant Agriculturist Fred E. Brooks.................... Associate Entomologist Frank B. Kunst..................... Assistant Chemist Leicester Patton.........................ssistant Chemist Chas. E. Weakley, JR . ................. Assistant Chemist W. J. Wніте............................. Bookkeeper

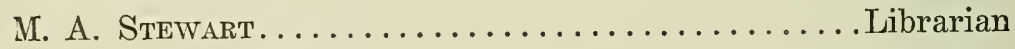

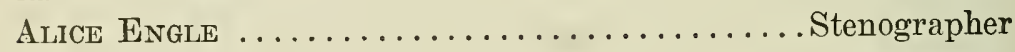

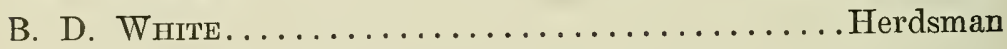


Digitized by the Internet Archive in 2010 with funding from Lyrasis Members and Sloan Foundation 

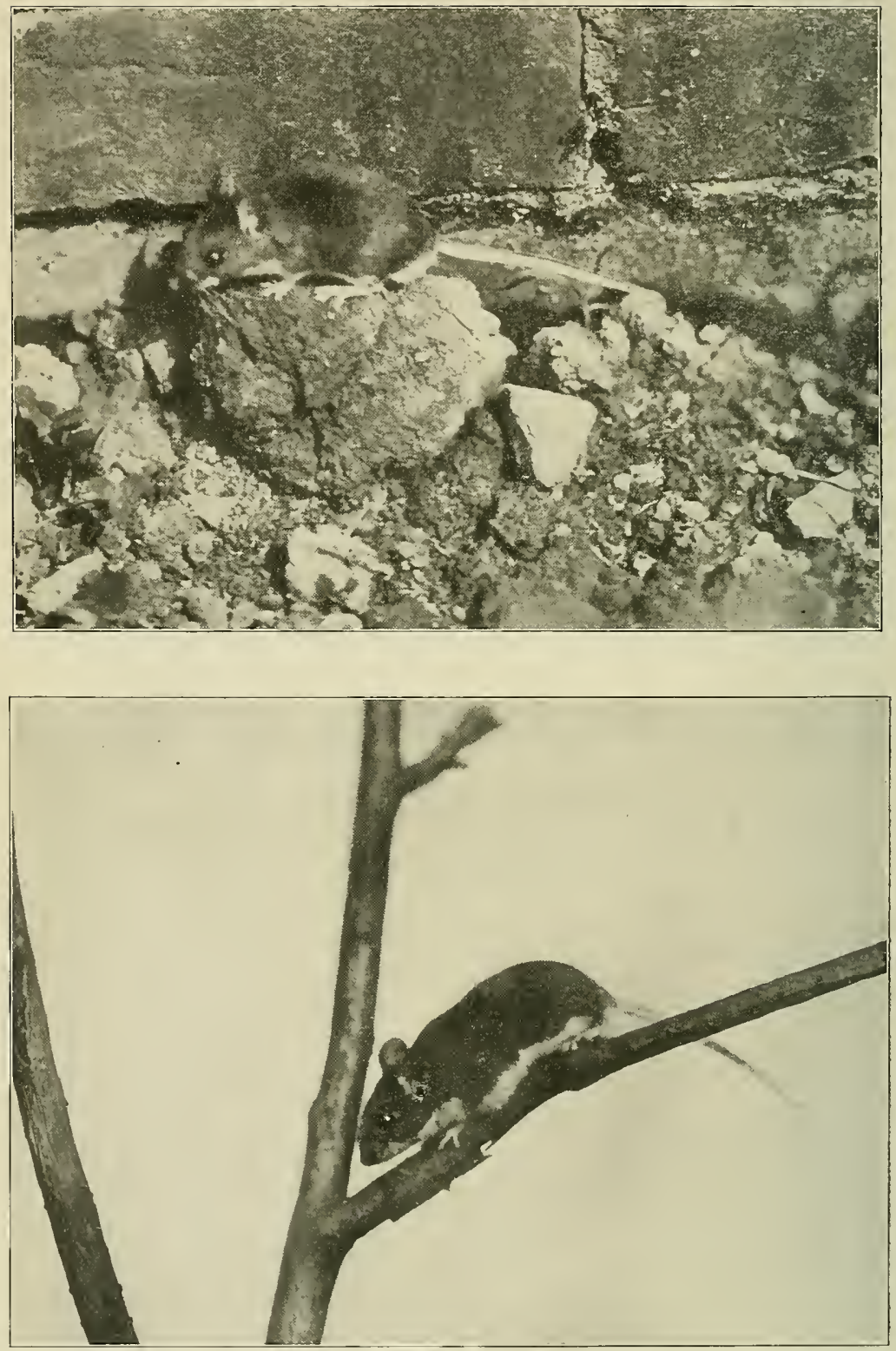

White-footed Mouse, Peromyscus leucopus. This species lives in the woods and does not often enter houses. Very abundant in most parts of West Virginia. 


\section{Notes on the Habits}

\section{of \\ Mice, Moles and Shrews.}

(A Preliminary Report.)

\section{INTRODUCTION.}

On every ordinary farm in West Virginia there is a host of little mammals that live in nests, runways and burrows above, or just below, the surface of the gromnd. These mammals represent the smallest of our fur-bearing animals and comprise several species of mice, moles and shrews. Including the common house mice, the white-footed or deer mice, and the jumping mice, which only occasionally use the surface or underground runways, we have within the borders of the state not less than fifteen distinct species of these little mammals.

The several species which for the sake of convenience are here grouped together, in reality represent two widely separated classes of animals. All the true mice are rolents, or gnawing animals, of the order Glires and are both herbivorous and carnivorous in their feeding habits. The group is represented by such larger animals as rabbits, squirrels and woodchucks. The moles and shrews belong to the order Insectivora and in feeding are almost strictly carnivorous. They have no very near relatives among the larger mammals but in a general way may be likened. to the minks and weasels. 


\section{DISTRIBUTION OF SPECIES.}

Several of the species are limited somewhat closely in their geographical ranges to certain life-areas; thus in the Canadian zone of our higher mountain regions the dominant forms are, as a rule, different from those commonly met with in the Austral zone of our lower elevations. In all situations, however, from the spruce forests and moss beds of our higher mountain tops to the grass and grain farms of our lower valleys, there may be found representatives of the mice, moles and shrews, some of them, usually, in great abundance. In their habits and manner of living they are, as a rule, secluded and unobtrusive, and a person may take daily walks through fields and woods that are thickly populated with half a dozen different species and rarely catch a glimpse of one of them. A little investigation, however, will surely reveal their burrows and paths extending through the ground or beneath lodged grass, decaying weeds and leaves, fallen $\log$ s, stones, or rubbish of any kind that may be lying on the ground. These burrows and paths form one of the most universal and unmistakable evidences of the presence of these animals. Unfortunately, some of the species have other ways of attracting our attention. The house mouse, for example, is always obtrusive and claims notice in a hundred well-known and obnoxious ways, the meadow mice occasionally raid our orchards, gardens, flowerbeds and grain fields and the moles throw up conspicuous mounds and ridges of earth in yards and lawns and in other grassy places.

Notwithstanding the abundance of the animals there will sometimes be long periods during which the depredations of the meadow mice and the imheavals of the moles will scarcely be noticed on the farm. At the same time the wellbeaten roads and burrows will remain, and, winter and summer, will form an intricate system of passages and runways, often extending to all parts of the farm and showing that the animals are still present and active, although for the time being they have ceased to be troublesome. It is obvious that at such times they do not discontinue, or even 
rednee, their feeding and the nature of the foot taken during these periods of propitious behavior should not be without interest to the farmer.

Soils that are frequently cultivated and fields of closely cut grass are the least subject to infestation by any of the species except the mole. Sod ground is one of the farorite hunting resorts of this latter animal.

\section{ABUNDANCE.}

The seclusion in which these animals live makes it difficult to form an intelligent idea of the numbers in which they actually occur. Their abundance undoubtedly far exceeds the popular notion in regard to the matter, and, if it were possible to give here the figures representing the exact mouse, mole and shrew population of West Virginia, the statement would probably be more often discredited than otherwise.

For several years I have been devoting considerable time to a study of the distribution and habits of these little mammals in different sections of the state. In pursuing this study I have necessarily collected hunitreds of specimens, principally by trapping. In systematically collecting over one piece of ground for several weeks at a time some estimate will naturally be formed as to the number of individuals that frequent a given area. I have several times, and under varying conditions, collected in this systematic manner and as the work has been carried on I have from time to time revised and extended my estimates as to the average number of animals occurring per acre in the localities studied.

Of the total number of all species found in the average locality, it may be estimated that half will be moles and shrews and the other half mice. 


\section{FOOD HABITS.}

It has been demonstrated by several experiments that some of the more common of these animals, such as the common meadow mouse, Brewer's mole and short-tailed shrew, will consume a quantity of food daily, equal to or greater than their own weight. It has also been shown, for all the species that have received any considerable amount of study, that their feeding habits have a more or less direct bearing upon agriculture. The moles and shrews, as has been stated, feed almost exclusively on animal matter, and on account of the number of insects which they consume that are detrimental to the growth of farm crops they may be regarded as being among the more useful of our wild mammals. The mice are in the main vegetable eaters and attack a great variety of plants that are useful to man, and for this reason may be classed as injurious. This classification of the mice, however, is arbitrary, and the group needs further specifical study before it is established that there are not some exceptions to the commonly accepted rule.

The destructive habits of the house mice and meadow mice in buildings, gardens and fields are well-known, and by the misdeeds of these species other animals, that are so unfortunate as to be mouse-like in appearance, are ali but universally judged and condemned. The average dweller in the country is prone to look with disfavor upon any animal that may be termed hawk, snake or mouse, and be the species what it may, if it answers to any of these names and comes within reach of the farmer, its life is apt to pay the penalty. The moles and shrews are good examples of animals that are unwisely dealt with after this fashion. They have proven themselves beneficial to the farmer, and yet the dog, cat, trap, poison, or other agency that will destroy moles and shrews is esteemed almost as highly as though it were equally effective in putting an end to so many house mice.

These beneficial animals, the moles and shrews, are usually killed in good faith, for the mistaken idea prevails that they are vegetable eaters and that they share in damaging potatoes, young 
fruit trees, the bulbous roots of flowering plants, etc., for which the different species of ground-dwelling mice are alone responsible. It is not to be wondered at that the moles and shrews are blamed for the mischief done by the meadow mice for they habitually frequent the same sort of places and are very naturally judged by the company which they keep. I once caught in ten days seven meadow mice, one white-footed mouse, one Brewer's mole and eleven short-tailed shrews in a single, underground runway in a grassy orchard in Upshur County. I have often trapped shrews in the identical runways used by the mice in getting to such articles of vegetable food as are mentioned above, and yet when either the shrews or moles were confined and given only such food, they invariably divested themselves of all unfriendly suspicion by dying of starvation after no more than marking with their teeth the food articles at hand.

\section{ECONOMIC IMPORTANCE.}

The economic importance of the mice, moles and shrews may be likened to that of the birds, although they have received less study and their habits are far from being as well understood. In so far as the species are concerned the birds, of course, greatly outnumber the mammals; but I believe if an average could be made of the number of individuals of both classes that are present and active in West Virginia at all seasons of the year, the latter might prove to be almost as numerous as the former. The migration of birds greatly reduces their number during the colder half of the year, whereas all the mammals under consideration, with the exception of a few of the less common species of mice which hibernate, are present and active the year round.

The amount of injury done by mice in houses and fields will compare very well with the loss on the farm from English sparrows, crows, hawks and fruit-eating birds, while the good accomplished by the beneficial species of each class is also comparable. The greatest material service of birds to man is, no doubt, the destruction of injurious insects, and, while the birds 
are busy above the ground in carrying on this work, the moles and shrews are equally busy in their chosen hunting-grounds in destroying similar pests. It often happens that a single species of insect at one stage of its development will inhabit the feeding places of birds and be destroyed by them, and at another stage will live in the ground and furnish food for the mammals. For example, the insectivorous birds will pursue May-beetles, elickbeetles and owlet-moths while the moles and shrews will be digging for white-grubs, wire-worms and cut-worms, which are but the immature forms of the same insects. When opportunity offers, however, the moles and shrews will not object to craunching a May-beetle or other adult insect any more than a robin will object to swallowing a white-grub or cut-worm.

\section{GENERAL STATEMENTS.}

There is a notable lack of literature on the life-histories and habits of moles and shrews, as well as of several of our common mice. The meadow mice have received considerable attention from investigators and writers in recent years, and an excellent bulletin has just been published by Mr. David E. Lantz, of the United States Biological Survey, entitled "An Economic Study of Field Mice." This bulletin gives a comprehensive account of the distribution, habits and methods of combating three species of meadow mice; namely,- the Common Meadow Mouse, Microtus pennsylvanicus, the Prairie Meadow Mouse, Microtus ochrogaster, and the Pine Mouse, Microtus pinetorum scalopsoides. The bulletin may be read very profitably by any one who is interested in these rodents.

The secretive ways of these little mammals make it a diffcult matter to observe accurately their habits, and there is yet much to be learned pertaining to the economic importance of most of them. This paper does not set forth the final results of the work along this line which has been planned by the entomological department of the Experiment Station. It has been prepared partly by compilation and partly from original observations, and is being sent out with the hope of stimulating an 
interest in a subject whieh is certainly of great importance to farmers and which in the past seems to have been unduly neglected.

The illustrations used are from photographs and drawings made especially for this publication. Some of them were procured only after the expenditure of considerable time and patience. It is hoped that they will enable the reader to distinguish between the beneficial and injurious speeies and assist in ereating a wider interest in the matter of encouraging the presence of our animal friends, as well as that of dstroying those species that are hurtful. 


\section{SHORT.TAILED SHREW.}

(Blarina brevicauda Say).

Called also Mole Shrew, North Eastern Mole Shrew, Large Bob-tail Shrew and Large Blarina.

Order Insectivora.

Family Soricidæ.

The short-tailed shrew is taken here as the most common representative of its family in West Virginia. It is distributed generally throughout the State, being found most often in deciduous woods, weedy or grassy fields, along fences, or in any location where there is shade or where decaying vegetable matter affords a complete or partial covering to the ground. Its geographical range, as given by Rholes, is "Canadian, transition and upper austral zones; Atlantic Ocean to Nebraska and Manitoba; Quebec to Virginia ; replaced southward by B. carolinensis, a distinct species."

Full-grown specimens are about five inches in length; tail one inch. Form rather stout and pig-like, legs short, nose pointed. Color sooty-plumbeous or lead-colored above, becoming slightly lighter below. Fur fine and glossy and varying in depth of color with change of light. Eyes very small and inconspicuous, ears small and hidden in fur, teeth tipped with dark chestnut.

The shrews frequent underground burrows and surface runways and may oceasionally be seen traveling openly over the ground in fields and woods, evidently in search of food. They are active both night and day and do not hibernate. When frightened, or while engaged in fighting with other animals, or occupied in family altercations they emit a strong, disagreeable odor. This odor evidently renders them distasteful in a measure to other predacious mammals and birds, as shrews are frequently killed by them and left uneaten. 


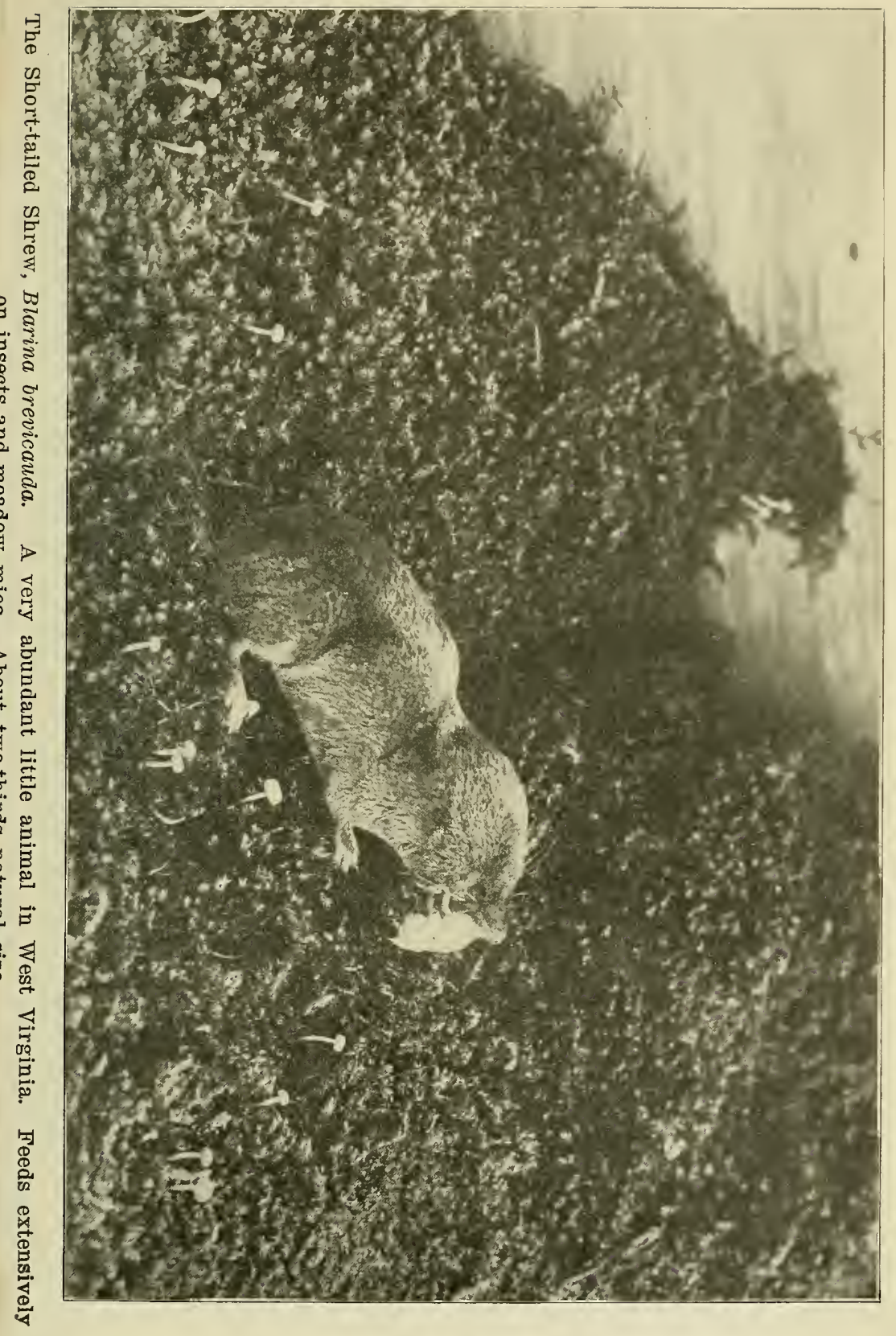



The species is very abundant throughout its range. The food is animal matter of a great variety of kinds, but chiefly insects, worms, mice and snails. In disposition they are nervous, ill-tempered and rapacious. They do not hesitate to attack animals larger than themselves and in confinement will kill and devour their fellows.

Considering the abundance of these animals it seems strange that the name "shrew" has not come into more general use, especially among persons who live in the country and see them often. When referred to on the farm they are almost invariably designated "mole" or "mouse," and the name "shrew" is scarcely recognized as belonging to a North American animal. The shrews constitute a family by themselves, however, and may very easily be distinguished from the moles by their smaller size and mouse-like fore feet, and from the mice by their pointed nose, small eyes and finer fur.

By way of emphasizing and amplifying these statements in regard to the characteristics of this species, I cannot do better than to quote at length here from the writings of several recognized authorities on the mammals of this country.

T). E. Luntz. "The Large blarina (Blarinu brevicuud" Say) is well distributed in eastern Kansas, and is probably found throughout the state. It is found in the woods and in the fields, and lives in shallow tunnels, which it makes by pressing the soil aside, after the manner of a mole. These tunnels may often be seen on the surface of the ground. The color is uniform dark plumbeous above, a little more ashy beneath, the feet brownish. When full grown it is about four and a half to five inches in length.

“***** Our knowledge of the shrews is meager. They are mostly nocturnal in their habits and, therefore, seldom seen. We know that they feed almost entirely on insects and, from observation of specimens kept in confinement, we suspect that they destroy other small mammals, and even that they sometimes kill and devour other shrews. At least, they are cannibals when in confinement, and only the strongest survive in a cage. In trapping and poisoning small mice I have often come upon partly devoured specimens, and have suspected that shrews were responsible for the work.

"There can be no doubt of the usefulness of this genus in destroying noxious insects. Shrews should not be destroyed. Unfortunately, 
cats and owls do not discriminate between shrews and mice, even if the farmer does; and so the shrews are likely to become less plentiful as settlement becomes more dense. I have frequently found dead shrews in hollow trees occupied by the screech-owl." (Bull. 129, Kansas Experiment Station, p. 394, 1905.)

Samuel N. Rhodes.. "This species (Short-tailed Shrew) stands pre-eminent above all others of our mammais in its abundance and universality of distribution in all conceivable situations. Not a place have I trapped over in the two states (New Jersey and Pennsylvania) but what it was among the first species to be caught. It is found in our deepest, coldest mountain ravines, on the stony, barren mountain top, in the banks and valleys of low tidewater streams and the maritime marshes, and delights in roving from the cool sphagnum bogs of the New Jersey cedar swamps, where the temperature may be below 60 degrees, to the hot sand barrens of the adjoining fields with a midday heat of 110 degrees. Forest and plain, sand and clay, barren or fruitful fields, back woods and dooryard, heat and cold, wet and dry, day and night, have common charms for this little cosmopolite.

"It is supposed by some observers that the fetid odor emitted by certain glands of this species, more particularly the male, causes its rejection bý all preying animals, as cats, dogs, foxes, minks, skunks, weasels, owls and hawks. To a degree this is true, and I have found them lying dead in open places in the woodland or along lanes, paths and roads where they had evidently been dropped by foxes, and owls, as the rounds in the body showed. That they are not always rejected may be seen by examining the lists of stomach contents and pellets or rejects of several species of hawks and owls. Some cats and dogs will eat them. The most offensive males may be rejected, and I doubt not this odor has a deterrent effect upon would-be offenders, acting as a preservative of the species. The more I observe and inquire into the economy of the large mole shrew, the more I am convinced that it is locally the most potent factor in preserving the economic equilibrium among the smaller mammalia which the Creator established as conserving the highest good of the greatest number.

"It is surprising how few, even among very intelligent people, have the remotest conception of what constitutes a shrew. I venture that ninety per cent. of the persons I have conversed with on the subject have had no other idea of shrews than the kind depicted in Shakespeare's comedy, and when I gravely state to them that I have caught so many shrews the effect is rather amusing. Though rarely seen, even by the most curious observers of nature, the subject of this article far outnumbers any other species of native mammal found in eastern North America. Like other members of the family it is 
insectivorous, depending almost wholly on animal food for subsistence, and with its near kinsman the mole, which it greatly resembles, is supposed to feed principally on worms.

“* ***** In view of their great numbers we naturally, query what economic relations they bear to man and to nature. Undoubtedly the purely mechanical effect of their universal burrowing and rooting in the soil is an important factor in that economy. It is known that they subsist to some extent on vegetable food, chiefly nuts, but they do only indirect damage to agriculture by disturbing the roots of plants. On the other hand, there is little doubt that they destroy an amazing number of noxions grubs, beetles, and worms, and it is probable that the part they play as underground scavengers is important. They also do much in checking the increase of the native mice of our meadows and woodlands.

"Of the domestic habits of the mole shrew we know very little, and that, in a general way, would seem to point to anything but conjugal felicity or fidelity, and their fraternal relations may safely be set down as far below par.

“* * * * * The mole shrew builds a nest of grass and leaves in dry, underground situations, to which it resorts not only for its own shelter, but for that of its young. Four to six young compose a litter, and, as with our native mice, the young are born at all seasons of the year, though less frequently in winter." (The Mammals of Pennsylvania and New Jersey, pp. 193-195, 1903.)

Witmer Stone and William E. Cram. "There is a class of little beasts common enough throughout all our Northern States, yet hardly known by name or otherwise. Resembling the mice in outward appearance; in their manner of living and getting their food they may almost be said to copy the habits of the weasels. They have the lithe, supple bodies, and short legs of the weasel tribe without the characteristic slimness of form; their flesh, like that of the weasel's is dark, and strong smelling. This might be attributed to their similarly carnivorous habits, if it were not true that the flesh of most meateating animals is comparatively light-colored and tender.

"It might even be objected that the shrews are not truly carnivorous but insectivorous, the fact that they are actually the smallest of beasts rendering them powerless against all but a very few of their kindred.

"But ravenously fond of all kinds of flesh they certainly are, and I believe that the young of ground-nesting birds and perhaps young mice are frequently eaten by them. It would not greatly surprise me to discover that they occasionally attack creatures larger than themselves. Of the several distinct species that should be found in most of the Eastern States, I have found but one really abundant. This 
one is catalogued as the mole shrew, and is found almost everywhere in great numbers. ***** They are obstinate, savage little brutes, but are unquestionably of immense service to the farmers, spending their lives in a most vigorous pursuit of insects of all kinds.

“*** Their keen noses enable them to scent meat at a considerable distance, and when they have succeeded in finding any that may have been left by larger hunters, they fall upon it ravenously, tearing at it and devouring it.with all the ferocity of wolves.

"One that I caught in a trap had already, when I found it, disposed of the raw meat, which had served as bait, and when confined in a cage immediately seized upon whatever meat was offered it, whether raw or cooked, without discriminating between kinds. Beef, pork and cold chicken-all went the same way, while the fury of his appetite was being appeased. Both in eating and drinking the projecting taper-like nose or trunk was turned up in order to enable him to use his mouth more freely, for a shrew's mouth opens from beneath almost like that of a shark. The sensitive trunk is doubtless of service in polking about beneath the leaves and in soft earth after worms, of which the mole shrew is particularly fond.

"Many of them take up their winter quarters in cellars where they forage around in dusky corners for worms and insects, or help themselves to whatever meat is left within their reach. Their holes are dug in the surrounding soil and are probably being multiplied and extended throughout the winter in search of worms.

“***** None of the shrews appear to hibernate, and whether the mole shrew ever passes the winter in burrowing about in the ground beneath the frost, or not, is hard to determine. The genuine moles are believed to occupy themselves in this manuer all winter long and, of course, it is quite possible that the mole shrew may do likewise, but I have my doubts about it.

"At all events, numbers of them are out on the surface of the snow, even in the very coldest weather, when the ground beneath is like a stone. Part of their food at such times is obtained by gleaning after the owls and foxes and other hunters of the woodland. If they depended on this alone most of them would starve long before spring, as even in warm weather they require food oftener than almost any other creature of their size, and though insects in small numbers are always to be found on the snow, these would hardly suffice to appease a mole shrew's hunger. I believe that they get the greater part of their food at this season by burrowing about among the dead leaves beneath the snow in the forests, gathering the dormant insects that habitually pass the winter in such places." (American Animals, pp. 180-182. 1902.)

Theodore Roosevelt. "When a boy I captured one of these mole- 
shrews and found to my astonishment that he was a bloodthirsty and formidable little beast of prey. He speedily killed and ate a partially grown white-footed mouse which I put in the same cage with him. (I think a full-grown mouse of this kind would be an overmatch for a shrew.) I then put a small snake in with him. The shrew was very active, but seemed nearly blind, and as he ran to and fro he never seemed to be aware of the presence of anything living until he was close to it, when he would instantly spring on it like a tiger. On this occasion he attacked the litttle snake with great ferocity, and after an animated struggle in which the snake whipped and rolled all around the cage, throwing the shrew to and fro a dozen times, the latter killed and ate the snake in triumph. Larger snakes frequently eat shrews, by the way." (Scribner's Magazine, Vol. XLII, No. 4, p. 385, Oct. 1907.)

Robert Elliott. "Short-tailed shrew, Blarina brevicauda (Say). More mole-like in appearance than any member of the next genus. (Sorex.) Besides destroying innumerable injurious insects in the course of a year, this industrious mammal is a persistent enemy of mice, following them into their burrows and killing them there. Com. mon in Ontario.

"* * * * * That the distinction between a shrew and a mouse is not more clearly known is a decided misfortune to both the farmer and the shrew. Meadow mice feed on the farmer's crops and are generally treated as they truly are-that is, unmitigated pests. Shrews feed on insects and (in the case of one species, at least) on those very mice the farmer so cordially dislikes. Yet to the average farmer every little furry creature that runs through his fields is merely a mouse, nay, even worse than that, if any distinction is made at all, it is usually against the poor little 'shrew-mouse'-an unreasonable prejudice allied to superstition." (Twenty-seventh Annual Report, Entomological Society of Ontario, pp. 19, 20, 1896.)

A. Franklin Shull. "**** * Two articles of food of Blarina have been so far męntioned, namely, snails and voles. (Meadow mice) * * * The only quantitative evidence obtained in the field in regard to the vole diet was found at the nest mentioned above as having been made exclusively of the hair of this animal. Beside this nest, thrust into the loose peat, were the bodies of two freshly killed meadow voles and that of a third half eaten. In addition to those there were several handfuls of hair in which were mixed legs and tails enough for about twenty voles. I could not know how long it had taken to accumulate this mass. The hair was still moist but was packed so close that moisture would be retained a long time even in the dry soil in which the nest was located. 
"To determine more accurately the quantity of mice and other foods eaten by the shrew, experiments were made in the laboratory. A shrew was kept in confinement for over five weeks, in a wire covered cage in which earth was placed to a depth of about. $10 \mathrm{~cm}$. When practicable, live food was furnished. Among the various foods tried were meadow voles and house mice (Mus musculus), May beetles (Lachnosterna) and their grubs, moth larvæ, other insects and pupae, earthworms, snails, sowbugs, carrots, crackers, roots of grasses and other plants. None of the last three articles were ever touched as food. ******** other insects such as various ground beetles, giant water bugs (Benacus), and Hydrophilus triangularis, were furnished. All were eaten, but the ground beetles were the favorite. Other larvae of insects besides Lachnosterna were readily taken, even the "woolly bear of Pyrrharctia isabella.. Sowbugs were eagerly devoured. When live food was not to be had, beef was furnished, and was eaten readily. I made only two stomach examinations. One stomach contained an insect larva mutilated beyond recognition; the other the remains of a meadow vole, recognizable by the hairs swallowed with the flesh. Vegetable foods were invariably rejected, though Professor Reighard has captured the shrew in traps baited with nut meats scented with anise oil, and the specimens taken still had fragments of the nut meats in their teeth.

"**** Too little has heretofore been known of the shorttailed shrew to make an estimate of its econmoic importance practicable. Stomach examinations are almost wanting, my own work including but two. However, from data concerning the quantities of food in laboratory and field, I have attempted an estimate of the economic importance of Blarina. **** For example one month's rations of voles alone would be 20 ; of house mice 30 ; of adult May beetles, 450 ; and so on.

"* * ** * *stimating the number of shrews as I have done at four per acre, it appears the number of meadow voles devoured by them on a farm of 100 acres in a year is $100 \times 4 \times 12 \times 8=38400$. Since this number can scarcely be supplied, the capacity of the shrews for keeping the voles in check is not strained. Where this quantity of voles can not be found, either other foods must be eaten in equivalent amounts, or the shrew is capable of subsisting on shorter rations or the estimated four shrews per acre can not exist. Farmers should take note of the economic value of Blarina. In their zeal to rid their premises of noxious animals, they sometimes kill indiscriminately anything that looks like a mouse. One of these animals evidently kills many more voles in a year than the farmer himself. 
"***** The short-tailed shrew is so well protected from its enemies that no animals appear to depend upon it for food. It is abundant and widely distributed. In security it devours such quantities of voles and insects that its, economic importance is considerable; and since, unlike the other common shrew, Sorex personatus, it is almost exclusively carnivorous, there is little to detract from its economic value." (The American Naturalist, Vol. XLI, No. 4SS, pp. 495-522, Aug., 1907. From observations made in Michigan.)

E. A. Samuels. "The animals of this family (Shrews) are small, some of them the most diminutive of mammals. Their habits are generally nocturnal, and none of one species hibernate, $I$ believe, as individuals are often seen in the winter busily engaged in searching for insects in their various forms, in and beneath piles of stones and rubbish. The shrews inhabit the woods, fields, and gardens, and being possessed of voracious appetites, they are continually active in destroying numerous noxious insects, of which their food almost entirely consists; consequently they are all eminently beneficial to agriculture, and are certainly worthy the protection of the farmer." (Report of Commissioner of Agriculture, p. 267, 1864.)

Ernest Ingersoll. "All the shrews are ceaselessly active, wandering about underneath leaves, old grass, and logs, and boring their way into loose loam or the punky wood of decaying stumps, in search of earthworms, grubs, beetles, slugs, and similar prey, including young mice and the fledglings of ground-nesting birds, and varying this fare by bites from soft-shelled beechnuts, tuberous roots, etc. They are astonishingly quick of hearing; are bold, pugnacious, and fierce, often killing and eating other shrews; difficult to keep alive in captivity, utterly untamable, and easily frightened to death." (Life of Animals, p. $70,1907$.

\section{SHREWS AND "CHESTNUT WORMS."}

My attention was first attracted to the abundance and economic value of the shrews in the spring of 1906. At that time I was making a study of insects that feed on nuts of various kinds and, in working out the life-histories of the several species under consideration, I found it desirable to add to my supply of "chestnut-worms," "hickorynut-worms" and "acorn-worms." During the previous fall I had had no trouble in finding large numbers of these worms in the ground beneath nut-bearing trees 
where they had gone to hibernate and to transform later into mature insects. In making a search in similar locations in the spring, I found that there remained only a very small per cent. of the number that was known to have entered the ground in the fall, the missing ones having evidently been devoured by some small animal whose burrows traversed the ground beneath the trees in every direction. Several mouse-traps were set in these burrows and in less than a week the traps caught over twenty short-tailed shrews under a single chestnut-oak tree. Some of the shrews were captured alive and kept in confinement and would feed ravenously on the worms with which I supplied them. One ate seventy-two large chestnut-worms, Balaninus proboscideus, in less than five minutes, while another gorged itself with nearly all the flesh of a full-grown white-footed mouse in the morning and in the afternoon of the same day ate thirty chestnut-worms at one meal.

A few white-footed mice were also caught in the traps but the larger number of shrews taken, and the avidity with which the captive individuals ate the worms given to them, seemed to justify the conclusion that the shrews had been the principal agents in destroying the worms. In many places, too, the animals in searching for the insects had apparently worked over the soil thoroughly between the burrows, which indicated the operations of shrews rather than of mice. The mice when caged, however, would also eat the worms and no doubt they hat aided to some extent in the good work done by the shrews.

Near the oak where the shrews were caught there stood a large chestnut tree that had produced a heavy crop of nuts the previous season. Beneath this tree I selected a spot at random and drove four stakes enclosing a plat of ground measuring six feet on either side. The plat was then marked off into blocks of one square-foot each and by removing the surface of the ground carefully with a trowel, one section at a time, a diagram was made of the location of all the burrows found. The figure below shows the distribution of the burrows on the thirty- 
six square-feet of ground. That burrows of the same kind in the surrounding soil were being used extensively by the shrews, I proved in the manner mentioned above, and by subsequent trapping near the same place.

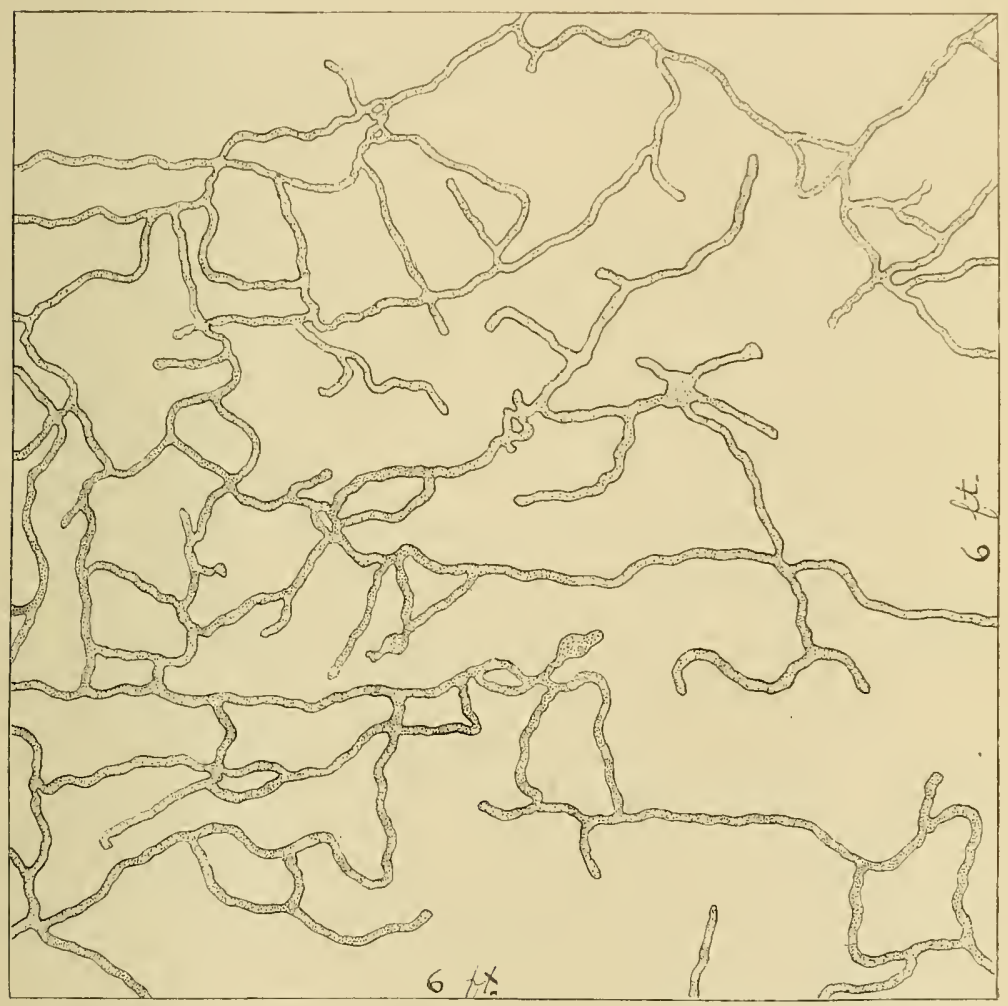

Diagram showing burrows used by short-tailed shrews in searching for insect food. The burrows occurred in thirty-six square-feet of ground under a chestnut tree in the woods. (Original.)

In many places the mechanical condition of the soil showed that the animals had turned aside from their well-beaten roads and had worked through the ground without leaving any per- 
manent displacement of the earth behind. In this way practically all the surface of the ground, to a depth of two or three inches, had been worked over and in removing the earth with the trowel only one chestnut-worm was found. From the number of chestnut burrs and wormy nut shells that were scattered over the ground at that point, it seemed probable that many more worms than this had originally entered the soil. If this were true the greater part of them had undoubtedly fallen a prey to shrews.

The interest awakened by these observations led me to inquire more fully into the habitats and general characteristics of these small mammals. As the inquiries have progressed many new lines of interest pertaining to the subject have suggested themselves which, for practical and scientific reasons, it has seemed profitable to follow up. Some of the questions bearing upon the economic status of the shrews have already been answered by investigators, but there yet remain many points, especially in regard to their feeding habits, that are unsettled. The economic status of the shrews depends largely upon the quality of food which they consume. They are known to feed largely on insects and mice and have therefore been' designated by nearly all writers on the Soricidæ as being highly beneficial. This designation is most likely entirely proper, and yet the probability that the shrews also feed on beneficial insects and birds' eggs and fledglings should not be lost sight of. The harm which they do in this way may offset in a measure the good resulting from their destruction of injurious species.

In endeavoring to obtain accurate data as to the insect food of the shrew, I have worked along three lines: 1st, examinations of the stomach contents of specimens collected in the field; $2 \mathrm{n} d$, studies of the foods preferred by individuals in captivity, and $3 \mathrm{rd}$, observations on the species of insects that live habitually, either as larvæ, pupæ or adults, in such places as are frequented by shrews. In view of the fact that these investigations are as yet far from complete, and that it is the present intention to 
publish the final results of the work at some future time, it seems desirable to give here only a few of the more significant observations that have thus far been made.

\section{DISTRIBUTION AND ABUNDANCE IN WEST VIRGINIA.}

In one of the quotations on a preceding page, S. N. Rhoads states that in Pennsylvania and New Jersey the short-tailed shrew is the most abundant of all native mammals, and Shull in another quotation estimates their average number per acre, for a point near Ann Arbor, Michigan, at four individuals. These observations entirely coincide with my own made in West Virginia. . I have found them very plentiful in fields and woods about Morgantown, in the glade lands and woods near Cowen, Webster County, in an old garden in Buckhannon, in a cellar and various outdoor situations at French Creek, and in other localities.

On October 17th, 1907, I lifted a small board that had been left lying on a bed of grass that grew in the corner of a fence enclosing an orchard at French Creek. A well beaten runway was noticed beneath, extending nearly the full length of the board. With the hope of catching mice or shrews, I set a mouse-trap in a little depression in the soil which I scooped out so as to bisect the runway, and then replaced the board. Within the next six days the trap caught nine shrews, and during the same period one other was caught within a rod of the place. This was proof that at least ten shrews had visited that particular rod of ground in one week, and there was good reason for believing that still others had been about the traps, but had not been caught. The trap under the board was baited with grains of corn and meat so as to attract both mice and shrews, but at the time only the one species was taken, though afterward several meadow mice were caught at the same place. This is only one of many examples that might be given to illnstrate the abundance of the shrews in West Virginia. 
ACTIVITY BY DAY.

Some writers suppose that the shrews confine their activities chiefly to the night, but I have found them but little less diurnal than nocturnal in their habits. They will enter traps almost as often by day as by night, especially if the traps are covered. Most of their operations are under cover, but they will frequently come to the surface and move about openly. Their tracks in the snow indicate this habit, and it is not unusual to see them making such excursions by daylight. I can recall two occasions when I watched individuals running about over the short grass of a pasture field and have frequently seen them in the woods traveling in like manner over fallen leaves.

On April 28th, 1906, while collecting insects in a woodland near Morgantown, I found an open, sunny spot where I stood quietly for some time to sweep for passing butterflies. While thus engaged, a rustling nearby in the dead leaves attracted my attention, and on approaching noiselessly the spot from which the sound proceeded I saw three short-tailed shrews running about over the leaves, evidently foraging for insects. They were hunting within a few feet of each other, and several times were seen to rush excitedly about as though in pursuit of some lively game. A slight noise made by striking my foot against the ground caused them to dive instantly under the leaves, but a moment later they reappeared and continued their search. I watched them thus for some time, but was too far away to distinguish what insects they were catching, if in Jeed they were after insects. At another time, however, in Ipshur County, I saw a shrew while similarly engaged flush a large, black cricket. The shrew made several frantic, but well-directed leaps for the cricket, caught it, and immediately darted out of sight beneath the leaves. The precision with which the shrew jumped toward its prey led me to suspect that the sense of sight is more perfect than the diminutive eyes indicate. 


\section{FOOD HABI'TS.}

Insects. - I have never givell a hungry shrew flesh of any kind that it would not eat. Insects of all sorts are devoured by them when in captivity and there is no good reason for believing that any of them would be refused by shrews when at large. A great per cent. of the common injurious insects of the orchard, farm and garden, as well as many beneficial species, spend normally one or more stages of their existence in just such places as the shrew selects for its hunting-ground. A list of the injurious species would include such well-known pests as grasshopper's, seventeen-year locusts, cut-worms, wire-worms, corn ear-worms, cankel-worms, "rose-bugs," white-grubs, Maybeetles, cucumber-beetles, plum-curculios, grape-curculios, graperoot-worms, potato-beetles, chestnut-worms, and many others, and of the beneficial insects such species as ground-beetles, tigerbeetles, certain species of parasitic hymenoptera, diptera, etc. No doubt examples of all these are eaten with more or less frequency by shrews.

The following table shows something of the feeding capacity of the shrews:

FOOD CONSUMED BY SHORT-TAILED SHREW. B. brevicauda.

Date.

1907.

Articles Eaten.

Weight.

July 22 , ( $24 \mathrm{hrs}$.) 1 young rat, 1 young indigo bird...... Not recorded July 23 , (24 hrs.) 1 young rat, 111 rose chafers, $M$. sub-

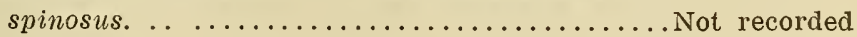

July 24, (24 hrs.) 1 young rat, 8 peach-tree borers, 1 cut

worm, 1 butterfly .................... Not recorded

July 25, (24 hrs.) 1 large beetle, Pelidnota punctata.

1 bumble-bee, 2 small fish.................... rot recorded

Oct. 19-22, (64 hrs.) 2 shrews, 28 large grasshoppers, 6

small white-grubs, piece of gray squirrel........57 grams

Oct. 23, (24 hrs.) 38 large white-grubs, (Allorhina and

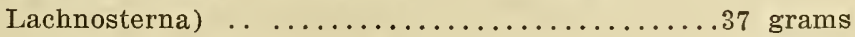

Oct. 24, (24 hrs.) 119 chestnut-worms, (Balaninus)....... 7 grams

Oct. 25, (24 hrs.) 117 chestnut-worms (Balaninus)....... 7 grams

Oct. $26,(24 \mathrm{hrs}$ ) 16 large white-grubs, (Allorhina)......21 grams 
The shrew used in the October test was only partially grown, weighing but 13 grams, whereas the weight of a fullgrown specimen will sometimes exceed 20 grams. On the $23 \mathrm{rd}$ day of this month the shrew ate a quantity of white-grubs equal to nearly three times its own weight. This was evidently an over-feed, as during the two succeeding days it acted stupid and reduced its food to about one-fifth the quantity eaten on the 23rd. On the 26th it appeared to be regaining its normal health and ate more freely. The daily average of foo taken was a little over 19 grams, a quantity equal to about one and a half times its own weight.

Mice.-It has been conclusively demonstrated by Shull that shrews under natural conditions will kill and devour mice. Their ability to overcome full-grown white-footed mice has been questioned, and, since meadow mice are considerably larger and more powerful than the white-footed kind, it would seem that they, too, would be more than a match for the shrews. I have made but few field observations along this line, further than to notice that shrews will devour dead mice which they find in traps. On several occasions I have confined full-grown shrews and white-footed mice together in a cage, and always the shrews have killed the mice, but sometimes they have succeeded in doing so only after a prolonged and bloody fight. I have never matched a full-grown shrew against a full-grown meadow mouse, though I have seen a shrew kill and devour a meadow mouse considerably larger than itself.

I recently placed a shrew, about two-thirds grown, in a box with a-mature and very large meadow mouse. They lived together for about a week before they were separated, but the relationship between the two seemed at all times to be decidedly strained. Each seemed to fear the other, although the mouse was at least four times the size of the shrew. I fed the two a great many grasshoppers, of which both were very fond. The one that got hold of a grasshopper first would keep it without personal violence being resorted to by the other for its possession. When the mouse was eating food that the shrew desired, the latter would often take a position near at hand, usually at 
the mouth of one of its burrows in the moss with which the box was partly filled, and indulge in a peculiar and rather amusing performance. With its month wide open and its snout and lips drawn back so as to expose its sharp teeth it would throw its head rapidly from side to side and give forth a peciliar, songlike chatter consisting of a series of rapidly repeated chirps, pitched on a high key, and varied every few seconds with a long-drawn, rasping note on a lower key. While thus engaged it would assume a perfectly fiendish look and express in the most realistic manner all the anger and envy and hate that was in its little heart.

House mice, white-footed mice and meadow mice, when confinet in a cage with shrews, will often manifest the most abject terror, and will jump and rush about as though panic stricken until exhausted. The evident hate and fear with which they regard the shrews indicate that they recognize in them a natural and puissant enemy which for reasons of personal safety they must avoid.

Birds.-All the information that I have been able to obtain indicates that the nests of certain terrestrial song-birds are sometimes robbed by shrews, although it must be admitted that positive evidence is wanting. In captivity the shrews will eat the eggs and young of small birds and there are good circumstantial reasons for believing that under natural conditions they will do the same whenever opportunity offers. The fact that several species of mice are also believed to molest birds' nests makes it a difficult matter to prove an actual case against the shrews.

Several years ago in early spring, I found the nest of a black and white warbler, Mniotilta varia, containing eggs, at the root of a beech tree in the woods of Upshur County. A few days later the nest was found empty, with a conspicuous hole about an inch in diameter through the bottom. An examination of the hole showed it to be the terminus of a small burrow that led off through the ground beneath the nest. 'This opening through the bottom of the nest seemed to account fully for the 
disappearance of the eggs, and was so like the work of a shrew that I had little doubt as to its origin.

During the spring and summer of 1907, I kept the eggs and young of several species of ground-nesting birds under close observation. A number of nests of such birds were found, and photographed, and subsequently visited at frequent intervals in oriler to note any signs of molestation by shrews or mice. In two instances nests were robbed in such a manner as to indicate the work of shrews. One of these nests also was that of a black and white warbler, and in this case was located beneath a small, overhanging stone in the same woods as the one described above. When first found it contained two half-fledged birds. The nest was at once photographed, and a week later was revisited, when the young birds were found to have Jisappeared. By turning back the mass of dead leaves about the nest a distinct burrow was found approaching it from beneath and penetrating the bottom. It is possible that at the time the nest was disturbed the birds might have attained size enough to have escaped their enemy by flying, but be this as it may. some little mammal had undoubtedly made an attempt upon them.

The other case was that of a whip-poor-will. Antrostomus vociferous, whose two eggs were found in the wools on a bed of forest leaves on June 14th. The eggs were photographed and within twenty-four hours afterward some little mammal mined up through the leaves directly under the eggs and broke both of them, devouring the contents and most of the shells. A monse-trap was forthwith set at the opening, and two days later a shrew entered the trap and was caught. This seemed to establish a pretty strong ease against the shrew. It is worth mentioning, however, that the next night after the trap was set a mouse of some kind visited it and left several pellets of excrement on the wood piece that held the wire mechanism together The broken birds' egg that served as bait was taken, but the trap was not sprung. The excrement was evidently that of a white-footed mouse, certainly it was not that of a shrew, as there is a marked difference in the appearance of the excrement of the two animals. The act of the mouse in visiting the spot 


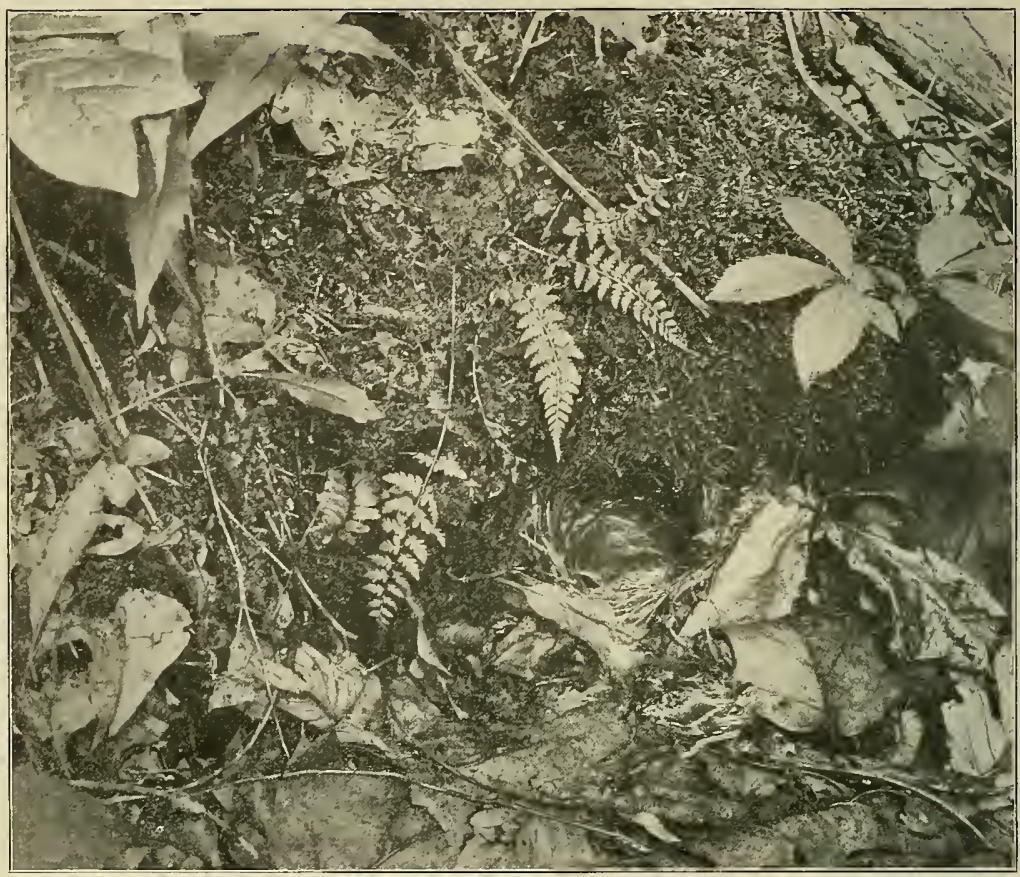

Nest of Black and White Warbler, supposed to have been robbed by shrews a few days after the photograph was made. Nest is just below the overhanging fern in the center of the picture.

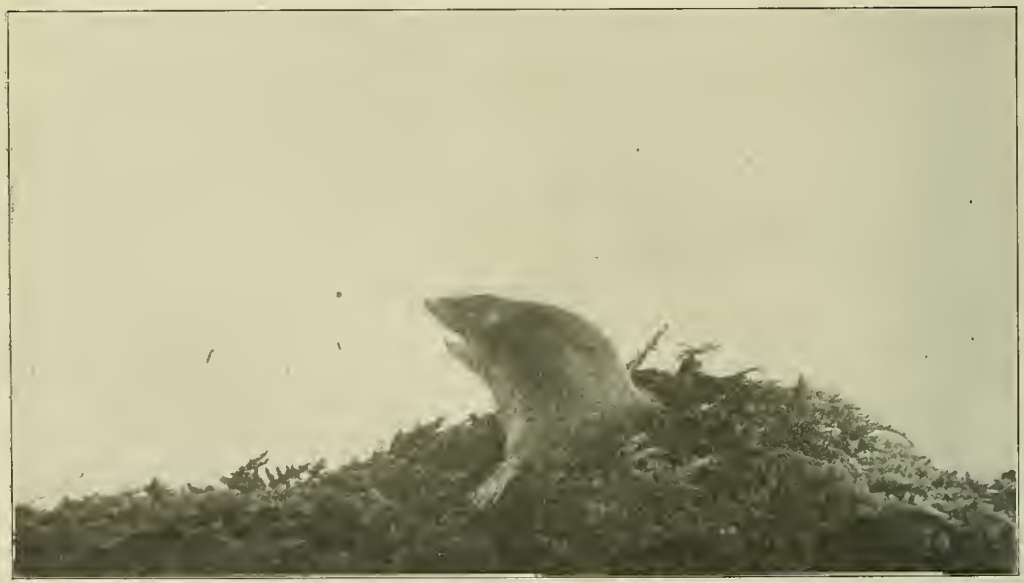

Young Short-tailed Shrew watching a meadow mouse from the mouth of its burrow in the moss. This shrew was in captivity when the photograph was made. 
so soon after the eggs were taken, pointed to it as the original offender, but the opening beneath the eggs resembled nore nearly the operations of a shrew.

Vegetable Foods.--Instances of shrews eating regetable matter have several times been recorded, but the known cases of such food being taken by the species under consideration are very rare. I have had specimens in captivity. when deprived of other food, to store a considerable quantity of grains of corm and nut meats about their nests, but could never discover that they ate of either. In two cases shrews have died of starvation with an abundance of corn, nut meats, and potatoes in their cages. I once found a branched piece of fibrous root in the stomach of a shrew, but the root was thread-like and less than an inch long. and might easily have been swallowed by accident in taking other food.

It is quite certain that so little vegetable substance of any kind is normally eaten by them that the question is hardly worth considering from an economic standpoint.

\section{NATURAL ENEMIES.}

The strong odor which the shrews exhale seems to inhibit larger animals of prey from eating them except when other food is scarce. It is doubtful, though, if this odor often prevents their being killed by such animals, for it seems to be the practice of several species to kill and then throw them aside. It is a common thing for domestic cats to bring shrews in from their hunts and leave them lying about uneaten. Foxes ar? known to have the same habit, and this may also be true cof some species of birds.

In the summer of 1893 I found the den of a red fox that proved to be the home of an old female and five half-grown cubs. The den was under a large stone and all about the place were scattered feathers, bones and other remnants of animal food, the most conspicnous being the dead bodies of short-tailed shrews. I did not count them, but there must have been twenty or thirty in sight. The mother fox had evidently brought them 
to her cubs, but as food more to their liking was abundant, they had used the shrews only to play with.

Dr. A. K. Fisher, in "Hawks and Owls of the United States," records the finding of short-tailed shrews in the stomachs of the following species of hawks and owls: red-tailed hawk, red-shouldered hawk, broad-winged hawk, sparrow hawk. barn owl, short-eared owl, barred owl, and great horned owl. Shrews of two nearly related species were found in the stomachs of the long-eared owl.

In the winter of 1898-99, Thomas H. Montgomery, Jr., observed the feeding habits of long-eared owls and short-eared owls at West Chester, Pa. It was ascertained by him that both species feed to a limited extent on shrews of the genus Blarina (American Naturalist, Vol. XXXIII, No. 391.)

In a bulletin published in 1906 by the Pennsylvania Department of Agriculture entitled "The Serpents of Pennsylvania," H. A. Surface, the author, states that shrews have been found by him in the stomachs of the spotted water snake, pilot snake, rattle snake and copperhead. In most cases the shrews were not specifically identified.

With the clearing up of the country these natural enemies are being thinned out, thus giving the shrews a better opportunity to multiply. This advantage is no doubt overcome, to some extent at least, by the necessary practices of agriculture, which interfere with the breeding and feeding places of the shrews, and thus tend to decrease their numbers.

\section{CONCLUSIONS.}

In the several localities where the short-tailed shrew has been studied, it has proven to be exceedingly abundant and a persistent destroyer of some of the worst pests of the farmer. In all probability it has the faults of robbing the nests of song birds and of devouring certain beneficial insects, but the good that it does in its constant pursuit of injurious insects and mice, far more than compensates for the loss resulting from these 
undesirable habits. From our present knowledge of the species we may therefore eonclude that it should be protected and encouraged under all ordinary eircumstanees.

\section{OTHER SPECIES OF SHREWS IN TEST VIRGINIA.}

In addition to the one described, the following shrews have been, or are likely to be, found in West Virginia.

Brown Shrew, Blarina parva (Say). Smaller than brevicauda. Dark-brown in color when mature, young iron-gray Distribution similar to brevicauda. Mueh less common.

Common Shrew, Sorex personatus (Geoffrey). This and the following speeies have long tails. Probably eonfined in tistribution to higher mountain regions. One of the smallest of mammals.

Smoky Shrew, Sorex fumeus Miller. Larger than personatus. Similar in distribution. 


\title{
BREWER'S MOLE.
}

\author{
Parascalops breweri (Bachman).
}

Also called Hairy-tailed Mole and Eastern Hairy-tail Mole.

Order Insectivora.

Family Talpidæ.

\section{INTRODUCTION AND DESCRIPTION.}

Three species of moles are supposed to inhabit West Virginia. Two of these, Brewer's mole and the star-nosed mole, Condylura cristata, have been collected by naturalists in several localities of the State. The third species, known as the "common mole," scalops aquaticus, undoubtedly occurs here, but I have never found it, nor can I obtain any positive evidence that it has been seen by others. Mr. Thaddeus Surber, of White Sulphur Springs, informs me that he believes he took this mole at Caldwell, Greenbrier County, in 1888, but is not positive in regard to the matter. The common mole is more widely distributed than either of the other species referred to and is on record from Pennsylvania, Ohio, Kentucky, Virginia, Maryland, and many other eastern states. Since it has been found in all the states bordering on West Virginia, it may very confidently be looked for here, by future collectors. especially in the southern and eastern portions of the state.

Brewer's mole is selected to represent. its family in this paper because it is the only species that I have so far collected, and, as a consequence, is better lnown to me than any other.

This mole is a little less than six inches in length, tail one and a fourth inches and covered with hair. Color, slate-brown with a silvery gloss; fur fine and short. It has the enormonsly enlarged fore-feet, diminutive eyes, and flexible, proboscis-like snout common to the moles. 


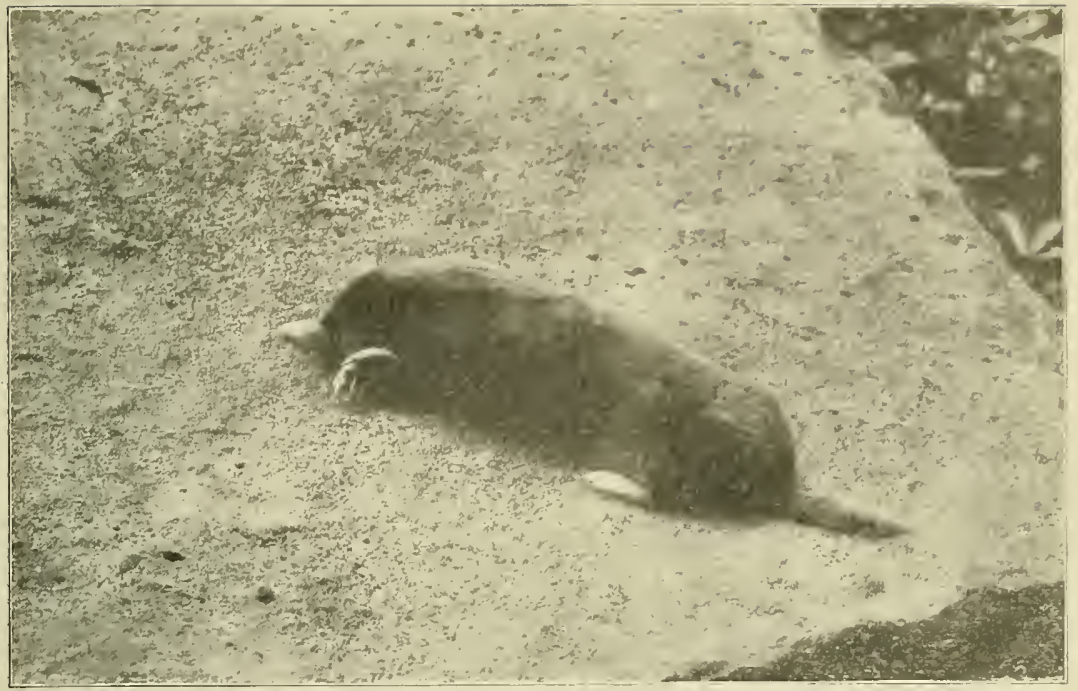

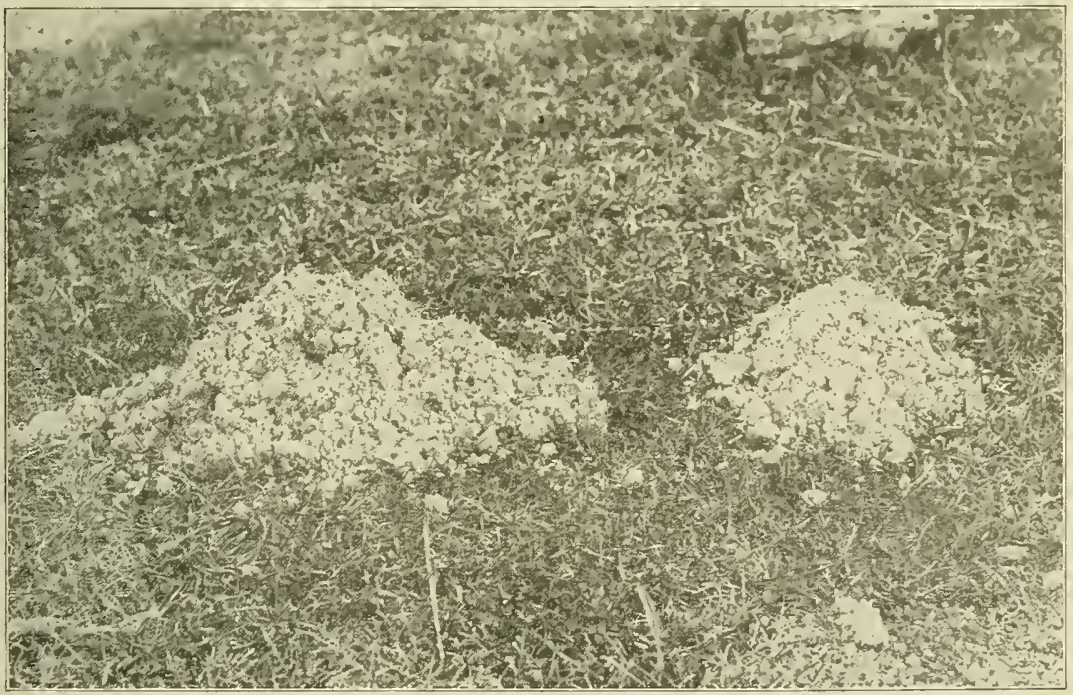

Brewer's mole and "mole-hills" on a grassy lawn. 
From the other two species mentioned, it may be distinguished by the following characteristics. From the star-nosed mole, by its shorter tail and the absence of radiating appendages on the end of the snout, and from the common mole, by the profuse growth of hair on the tail.

I have taken one specimen in which the hair on the end of the tail was white, but the color of all others that I have collected was dark throughout. With old individuals, white spot: on the head, breast, feet and tail are said to be not uncommon.

\section{DISTRIBU'TION.}

This mole is a northern species, but it follows the Alleghanies southward as far as North Carolina. In Pennsylvania it extends its range a considerable distance into the lowlands, especially on the western side of the mountains. The same is true of the species in this state, but farther south it seems to be restricted to the mountain regions. Mry observations on the moles have been confined principally to the hilly regions in the central part of this state. The locality, where most of my collecting has been done, is about thirty miles west of the main ridges of the Alleghanies and has an elevation of near 1,600 feet. Of about twenty-five moles collected in this locality in 1907, all were Brewer's moles.

\section{GENERAT HABITS.}

Brewer's mole, like other species of its class. spends its life underground hunting animal food and nesting. It is doubtful if this species ever comes willingly to the light. I have never caught a glimpse of one except as some disturbing influence in its life brought it to the surface.

When the ground is moist and soft it works near the surface and frequently throws up ridges and hills of earth several inches high. In dry weather when the ground is hard, and in cold weather when the surface is frozen, it mines at a greater depth. 
I have never found its nesting-place, and if descriptions of the nest and young of this species have been published, I have overlooked them.

At French Creek, Upshur County, I found this mole working in the soil of a grassy lawn, in fertile earth about a barn and other outbuildings, in an old woodyard where decaying chips formed a deep moist soil, in grassy orchards and in open places in the woods. An individual, or a pair, would frequently be found operating in one small pateh of ground for a week or more at a time. This activity at a certain place would be indicated by the Aaily appearance of new ridges and hills. I have never found more than two old moles working such a digging at one time, although in favorable spots, when the original operators were captured, others would soon appear and take their places. The surface disturbances of the soil seemed to occur most frequently in the early morning and late evening, and I came to the conclusion that the moles are more active by day than by night. I have several times seen the earth in the hills heaving, as a result of the activities of the animal within, during a downpour of rain at mid-day.

When a fresh digging was discovere much trouble to capture the one or two moles that were operating it by standing guard over the place for an evening or two with a long-handled shovel. When the motion of the soil in one of the hills showed that the mole was near the surface the shovel would be thrust under it and the mole thrown out with a shovelful of earth. I have on several occasions delved into a hill with my naked hand and secured a mole. In capturing them in this way I was surprised to find that they would not bite, as a mouse or shrew would most certainly have done under similar circumstances. At one time I caught a mole when about half a mile from home. I placed in in my coat pocket for safe keeping, but it proved to be so lively that to prevent its escaping, I was forced to hold it with my hand. It struggled and scratched most vigorously but did not bite, although held without regard to the proximity of the mouth. 


\section{FEEDING HABITS.}

The mole, like the shrew, has often been charged with eating vegetation of various kinils. Investigations have shown that the common mole does swallow a very little of such material but it is a question if this vegetable matter is not usually introduced into the stomach accidentally with animal food, or by swallowing the stomachs of herbivorous insects. Probably very few stomach examinations of Brewer's mole have been made. In several instances, however, the stomach contents of the common mole have been determined and the results published. The common mole and Brewer's mole are very similar in habits and since data as to stomach examinations of Brerrer's mole are wanting it may not be out of place to give here some accounts of what has been found in the stomachs of the nearly related species.

In 1894, Prof. H. Garman, of the Kentucky Experiment Station, examined the stomach contents of fourteen common moles, canght in the vicinity of Lexington, $\mathrm{Ky}$. He found that "every one of the fourteen moles had eaten animal food. Eleven of the fourteen had eaten earthworms and insects. Three had eaten insects alone. In the stomach of seven, traces of regetable tissue were found." (7th Annual Rept. Ky. Exp. Sta. pp. 41-45, 1894.)

Two years later (1896) Mr. Harry Wilson collected thirtysix stomachs of the same species in Pennsylvania. In determining the contents of these stomachs, the collector was assisted by competent experts.

Of these thirty-six stomachs, one was empty, 27 contained earthworms in connection with other material, 7 contained earthworms alone, 27 contained insects, 9 contained insects alone, 10 contained traces of vegetable matter and none contained vegetable matter alone. One mole had eaten six small fragments of green leaf, and another had eaten pieces of a grain of corn. (Bull. 31, Pa. State Dept. of Agr., 1898.)

Prof. L. D. Dyche, of the University of Kansas, examined the stomachs of sixty-seven specimens. Food was present in 
only fifty of these, the nature of which was as follows: earthworms 43.2 per cent., ground beetles 22.7 per cent., grubs and larw 22.8 per cent., vegetable matter 3.7 per cent, other material, largely insect eggs and ants, 7.6 per cent. (Trans. Kas. Acad. Sci., Vol. 18, pp. 183-6.)

Several years ago Mr. L. E. Adams published a very interesting paper on the Enropean mole, Talpa europaea, a species with habits similar to some of our American moles. He shows that the nests of partridges and pheasants are often robbed by this species and has the following to say in regard to the quantity of other food which it consumes. "The accounts of the short periods of starvation necessary to kill a mole are borne out by my observations. On one occasion I caught a vigorous mole, quite unhurt, and fed him at intervals during the day with about a third of a pint of worms, besides which he had several drinks of water. At night, about eight o'clock, I dug about a third of a pint of worms, and put them into his den (a packing case with earth at the bottom) and left him. In the morning I found him very feeble, thin and cold. I took him up in my hand and put his nose to some water, which he seemed to enjoy, but he was too feeble to tackle a worm, and presently, after a gentle convulsion, he died in my hand. I found on dissecting him that the stomach was absolutely empty, in spite of the fact that he had eaten every worm left for him." (Mem. and Proc. Manchester Lit. and Phil. Soc. Vol 47, part 2, 1902.)

\section{OBSERVATIONS IN WEST VIRGINIA.}

In my observations on Brewer's mole I have never found any evidence to indicate that it destroys the nests of birds, except that in captivity, the moles will eat small bird's eggs. When confined in a cage they feed on almost any kind of flesh that may be given to them and when two or more are put together, the stronger individuals kill and devour the weaker.

I kept one large mole in a box half filled with earth for thirty-three days. It was fed daily on earthworms, insects, and flesh of other kinds, of which it ate a surprising quantity. Sev- 
eral potatoes were kept in the box during most of the period but the mole did not once sample them. In the space of twentyfour hours, beginning at noon, June 12th, this mole ate 50 . large, white grubs, (Allorhina and Lachnosterna) one "chestnut worm" (B. proboscideus), one wire worm, onc cicada nymph, 45 larvæ of "rose bugs," (M. subspinosus) and 13 earthworms. The insects eaten weighed 42 grams and the earthworms. 24 grams, making a total of 66 grams. The mole itself weighed. 50 grams, or about four-fifths as much as the food taken. It should be mentioned here that it was the custom of this mole in eating carthworms to take one end of the worm in its mouth and then draw the body between its elaws in such a way as to force out all the earthy matter from the digestive organs. The weight, therefore, given for the earthworms, is likely a little too great, as this discarded portion would have weighed a few grams. However, after deducting it from the quantity given, that remaining would still weigh more than the mole itself.

The mole had been well supplied with food up to the time the test began, and I believe that the figures given represent a fair daily average of the food consumed by the mole. If correct, a single mole would eat in the course of a year something like 40,000 insects and worms, which would weigh over 50 . pounds.

At noon, on June 14th, I caught a mole and confined it in a box similar to the one in which the mole just described was kept. The mole was caught by hand and was not injured in any way. Water, but no food except potatoes, was given it. Early on the following morning it died of starvation. One of the potatoes was found to be slightly scratched as by the mole's teeth or claws, but, if any had been eaten, the amount was very. small. No trace of potato was found in the stomach. Later, another mole in captivity died in a similar manner when given nothing but potatoes.

The results of these experiments agree with what economic zoologists long ago found out, that the accusations made against moles of eating potatoes and other vegetables in the field, are 
almost, or entirely, groundless. They also agree with the account given by Adams on a former page, showing the inability of moles to undergo more than a very brief period of starvation.

\section{CONCLUSIONS.}

The foregoing observations on the food of moles show that so little regetable matter is eaten that this habit need not be taken into account in considering the relation which they bear to the farmer. This relation must depend largely upon the kinds and quantity of animal food that they consume.

The action of earthworms in the soil is usually supposed to be beneficial to the soil, and if this be true, the destruction of stuch worms by moles is an injury to the farmer. Furthermore, in a few cases insects that are known to be beneficial in their habits have been found in the stomachs of moles, thus showing that in this respect they are injurious to the farmer. In most eases, however, the insects found in the stomachs were species of noxious habits.

Of the fifty mole stomachs examined by Wilson and Garman, earthworms were present in 45 and insects in 38 . Garman estimates that in his examinations earthworms composed twothirds and insects one-third the bulk of food taken. Wilson does not estimate the relative quantities of each, but from his explanatory notes it would seem that a similar ratio might apply in his case. Dyche, in his examinations, found that earthworms composed 43.2 per cent. and insects at least 53 per cent. of the food. Over 22 per cent. of the insects he designates as "ground beetles" and these may probably be considered as being beneficial on account of their predacious habits. If we are to regard earthworms as being a benefit to the soil, then the stomach examinations of the 117 moles show that at least two-thirds of their food may consist of animal life that is helpful rather than injurious to the farmer.

This would seem to justify the destruction of moles in any way possible, but it should be remembered that the function of earthworms is not wery well understood and that the good re- 


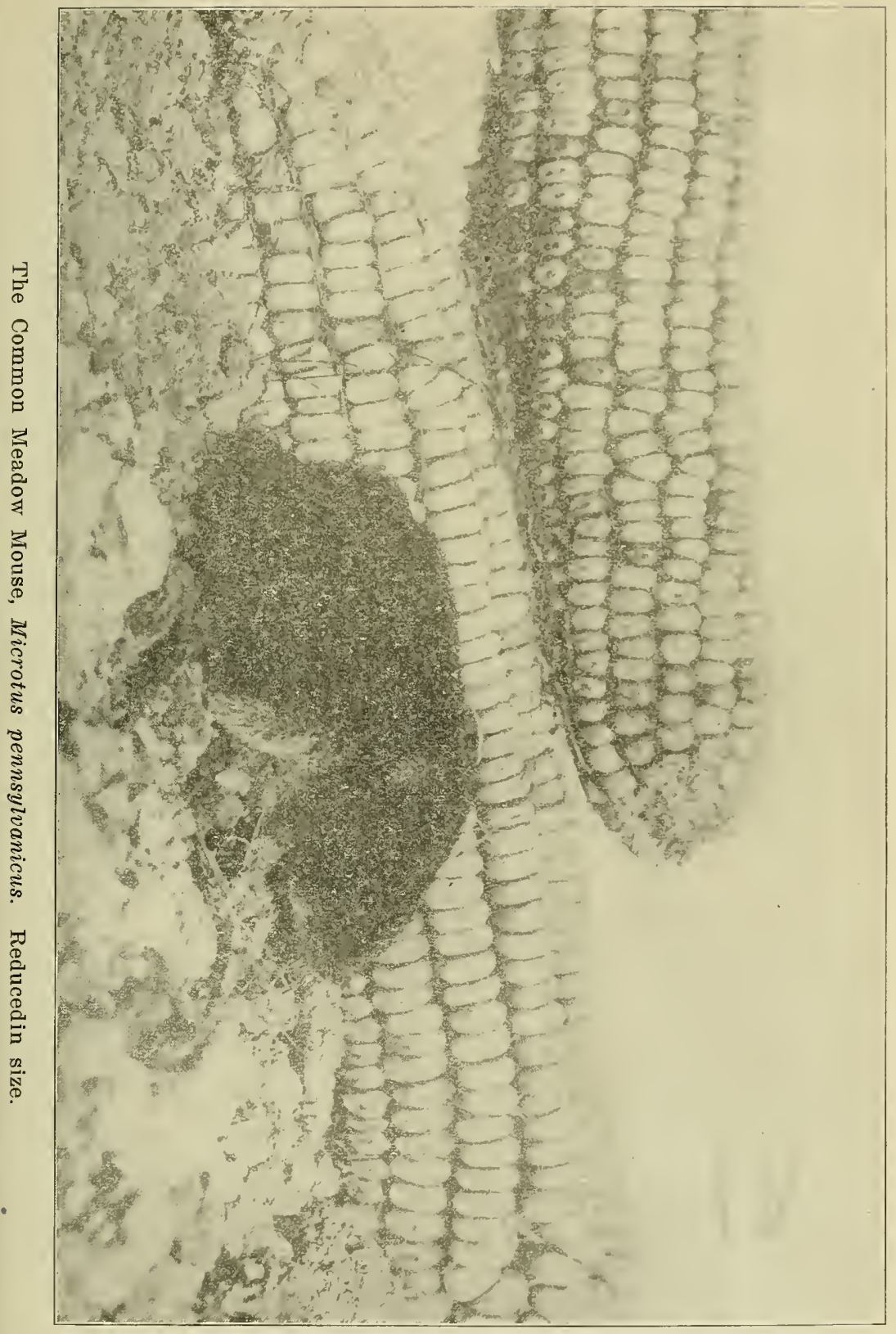




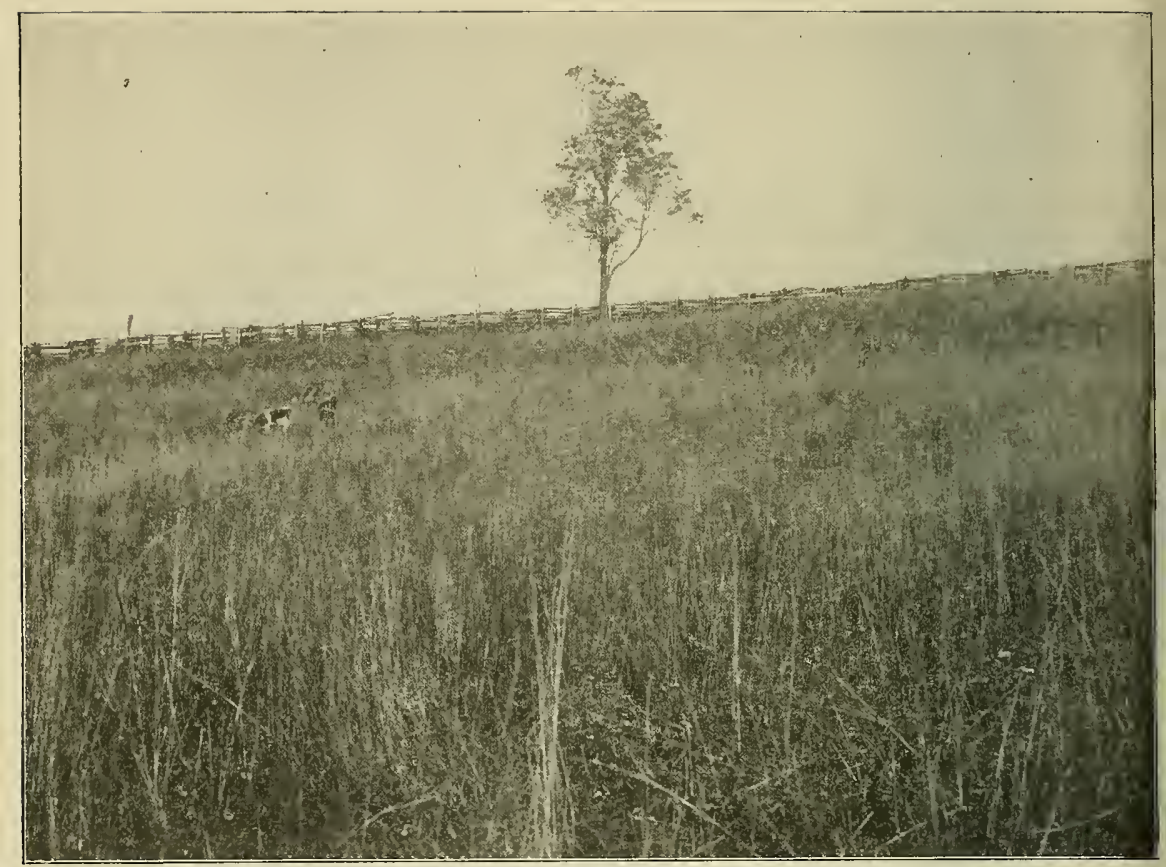

A "broom-sedge" field where meadow mice nest in great numbers.

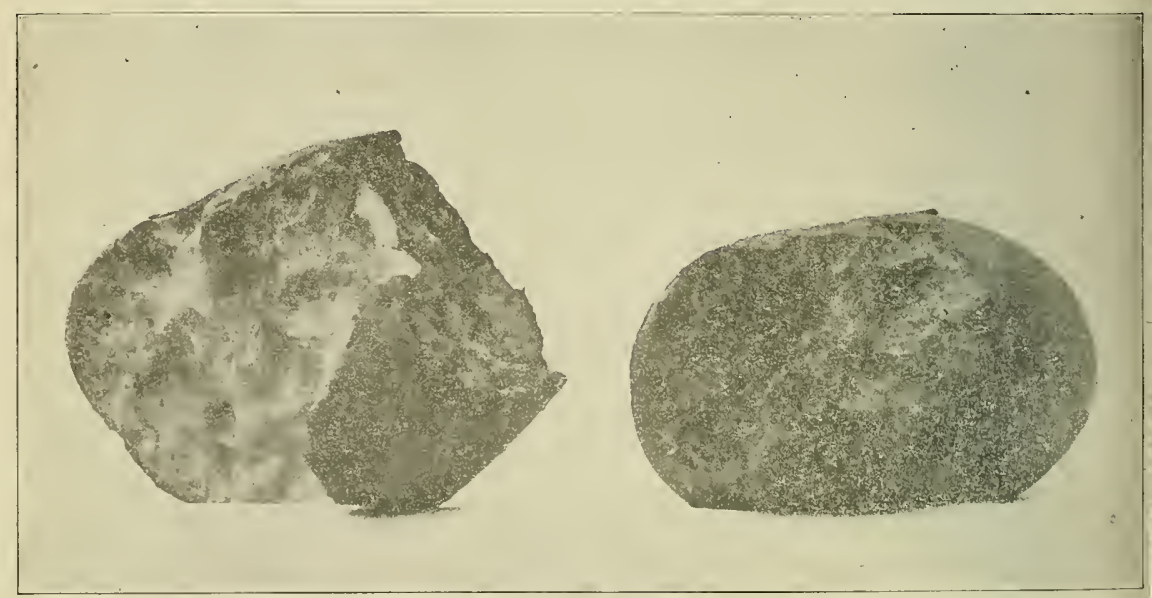

Potatoes partly eaten by meadow mice. 
sulting to the soil from their presence may have been overestimated. It is also possible that, if these worms were allowed to increase without check, their abundance would in time render them obnoxious, even though their presence in smaller numbers may be desirable.

It has been shown, furthermore, that the mole actually destroys large numbers of white grubs and other insects which are among the very worst pests of the farmer, and it is highly probable that the good that is done in this way far more than makes up for the loss of the innoxious and beneficial species.

In deciding for or against the mole, its habits of disfiguring lawns with mounds of earth, injuring plants by burrowing about the roots, and devouring beneficial forms of animal life, may be balanced against the good resulting from the better aeration and drainage of the soil due to its burrowing and to. its destruction of insect pests. It is quite true that the work of the mole is not entirely advantageous on the farm, but the good service it renders in ridding the ground of injurious insects is probably sufficient reason for submitting peaceably to the annoyance which it sometimes occasions, and giving it such protection as is possible.

\section{FIELD MICE.}

Order Glires.

Family Muridæ.

The different species of "fiel 3 mice" or "meadow mice" that are found in all parts of the country, are almost entirely responsible for that damage done to plants of various kinds, the blame for which is partly bestowed upon moles and shrews.

Of late years, these mice seem to have been multiplying abnormally in some sections of West Virginia. Serious damage has been done in orchards, gardens, potato fields and other places. The mice have girdled many young fruit trees in some of the finest young orchards in the state. Complaints of this kind have come from Berkeley, Lewis, Marshall, Mason, Pocahontas and Upshur Counties. 
Mulched trees, or trees growing in orchards where cover crops are nsed, are more liable to injury. Damage to strawberry plantations and to various kinds of garden crops have been reported from several localities. Irish potatoes and sweet potatoes have been especially subject to attack.

In the spring of 1907 , several instances were noted of seed potatoes having been eaten after they were planted, and before they had had time to germinate. This injury in some cases was so serious that the ground was replowed and used for other crops. A few complaints were heard of injury to newly planted corn fields by the mice burrowing along the rows, from hill to hill, and eating the seel corn before, or soon after, germination. In several cases, however, where fields were examined that were supposed, on account of the sickly appearance of the young plants, to be suffering from the underground attacks of meadow mice, it was found that the trouble was due to wireworms and corn root-aphids, instead of mice.

\section{"BROOM-SEDGE" FIELDS AS BREEDING PLACES.}

For a number of years there has been spreading over the cleared lands of some sections of the state, a kind of wild grass commonly known as "broom sedge." (The correct name for this plant is Virginia beard-grass, Andropogon Virginicus). The plant seems to prefer thin land and is partial to old pasture fields. It makes a dense and luxuriant growth in summer, and the yellow, leafy stalks remain standing into the winter until broken down by heavy snows. These "broom-sedge" fields make ideal breeding places for field mice. I have found scores of their nests, composed entirely of the blades of "broom-sedge," hidden near the ground among the denser growths of the same plant.

Serious injury to planted crops has several times heen noticed in fields lying adjacent to these "broom-sedge" fields. Examinations of such places showed that the mice had evidently invaded the cultivated areas from their protected retreats and breeding places among the "broom-sedge." The green stalks 
of this wild grass furnish a considerable portion of the food of the mice, as can be seen by the great number of eut-off, and partly eaten, stems and blades that are to be found about their nests and along their runways, where the plant grows.

The practice of burning over these "broom-sedge" fields in the fall, as soon as the growth is dry enough to ignite, has been followed in some localities. This practice is objectionable for several reasons, but where such fields are breeding great numbers of meadow mice which threaten injury to near-by cultivated crops, it may be advisable to burn them in order to clean out the mice.

\section{GENERAL DESCRIPTION OF FIELD MICE.}

The Bulletin entitled "An Economic Study of Field Mice," by David E. Lantz, which is mentioned on a preceding page of this paper, gives a concise account of two species of these animals that are found in West Virginia. The following excerpt of that bulletin is presented as representing the best information that has been published on the subject.

"The present paper deals with the habits of the common field mice of the United States. Small as these pests are, they inflict enormous injury upon the crops of the country. The aggregate loss to the farmers from this source averages not less than three million dollars annually, and in some years is much greater. The major portion of this loss is preventable and the object of this bulletin is to acquaint farmers, orchardists, nurserymen, and others with the most practicable preventive methods.

"Field mice of the genus Microtus have stout bodies, blunt rounded muzzles, small eyes, and short ears-often completely concealed in the fur. The tail is short and hairy; the soles of the feet are naked or clothed with short hairs, and have five or six foot pads. The incisors are broad and not grooved.

"About 165 living species and subspecies of Microtus have been recognized (1904), of which about 78 are North American. The genus is of wide distribution, covering practically the greater part of the northern hemisphere outside the tropical zone. The range of a single species is often remarkably great. Thus the typical form of the common meadow mouse of the United States (M. pennsylvanicus) occurs over a large 
part of at least twenty-five States, from Maine to the Dakotas and southward almost to 35 degrees north latitude.

"While the food habits of the various species of short-tailed field mice are remarkably similar, their breeding and general habits differ greatly. The variety of habitats is most striking. Some species prefer high ground, while others live in low, moist places. Occasionally the same species inhabits both sorts of localities. Some species live in forests, others in the open prairies. Some burrow under the ground like moles, while others make smooth paths or trails upon its surface.

"Except in cold weather, nearly all species can temporarily adapt themselves to moist surroundings; but a few seem to be almost as aquatic as the nearly-allied muskrat.

"The nests of field mice are compact bunches or globes, composed of grass blades and other dry vegetable fibers. They are placed in depressions in the ground, in shallow burrows, or supported on grass stems above the ground. In brush piles the writer has found them nearly a foot above the ground. Sometimes they are placed under flat stones or logs or under shocks of grain. The structures are so slight that a day's sunshine will dry them out after a storm, and yet they are so compact that the animals pass the coldest weather snugly housed in them under the snow. Trails, often of great length and worn smooth by constant use, lead to neighboring feeding grounds.

"While most surface nests are for shelter only, sometimes the young, especially of swamp species, are produced in them. However, the young of most kinds are born in underground nests and are rarely seen unless uncovered by accident. They are at first hairle:ss and blind.

"The common meadow mouse of the United States is one of the most prolific of our species. Estimating the normal increase at six young, with four litters in a season, and assuming that there were no checks upon the increase, the results are appalling. A single pair and their progeny in five seasons would amount to nearly 1,000,000 individuals. This calculation is under mark, since it is based on the assumption that the young do not breed until about a year old. The animals, however, mature very rapidly, and the spring young undoubtedly breed in the fall of the same year.

"In summer the principal food of these mice is green vegetation and unripe seeds of grain and grasses. As the season advances, ripe grain and seeds take the place of the immature; and in winter bulbous and other roots are in part substituted for stems and leaves. When convenient, and green vegetation is lacking, the bark of trees and shrubs becomes a staple food. It is mainly in winter that the apple orchards and young forest trees suffer from attacks of mice. 
"The quantity of green vegetation eaten by a single adult field mouse in the course of a year has been calculated at from 24 to 36 pounds. When one considers in connection with this estimate the great numbers of these animals in our meadows, swamps, and forests, the total quantity of food consumed by them appears so enormous as apparently to exceed the productive capacity of the soil. A thousand meadow mice in a meadow would require at least 12 tons of grass or other vegetation to maintain them for a year.

THE COMMON MEADOW MOUSE. Microtus pennsylvanicus (Ord).

The most familiar of American species of Microtus is the common meadow mouse ( $M$. pennsylvanicus). The average measurements of adults are about as follows: Total length, 6.6 inches; tail vertebræ, 1.8 inches; hind foot, 0.83 inch. The tail is always at least twice as long as the hind foot. The fur is long and overlain with coarse black hairs. In summer the ears overtop the fur. In winter the fur is longer, and of a duller color, and almost conceals the ears. The usual color above is a dark brown, against which the black hairs are not conspicuous. This shades off gradually into gray or tawny on the under parts.

"The vast range of this species has already been given. This mouse has its natural habitat in moist meadows and grassy borders of swamps, but it habitually extends its range into neighboring cultivated fields, waste lands, and open spaces on the border of timber lands. Wherever it occurs, it is normally the most abundant rodent. Nearly all meadows are full of the animals.

"In swamps meadow mice nest in burrows in dry tussocks or in bunches of grass above the surface of the moist ground. The nests are composed of grass or fibers of weeds made into balls, loose and of coarser materials outside, but compact and of finer stuff within, each having a small opening on the side near the bottom. From this opening two or more trails diverge, one usually leading into au underground tunnel which opens at some distance from the nest. Nests intended to receive the young are lined with the softest of accessible materials.

"The species under consideration never live in barns or outbuildings. Its nearest approach to human habitations is the stackyard or piles of wood or boards left on the edge of orchards or fields near houses.

"The common meadow mouse is especially noted for long winter excursions from its summer abode, hiding its movements under cover of deep snow. The journeys of the animals are not suspected until 
the snow disappears, when the trails can be traced to great distances. They reach wheat, rye, clover, and timothy fields and often extend into orchards, nurseries, lawns' and gardens, all of which are injured by the animals. Haystacks or shocks of corn and other grain are sure to suffer it left out over winter."

THE PINE MOUSE. Microtus pinetorum scalopsoides (Aud. \& Bach.).

"This pine mouse, called also the mole-like vole, has a wider distribution than the typical southern pine mouse ( $M$. pinetorum), and therefore is chosen as the representative of the group. The following account of its habits applies equally well to all pine mice.

"This animal has the wide, flat skull, the short tail, the small ears, and the short, dense, glossy brown fur characteristic of all the pine mice. The average measurements of three New York specimens, as given by Bailey, are as follows: Total length, about 5 inches; tail vertebræ $0.78 \mathrm{inch}$; hind feet, $0.64 \mathrm{inch}$.

"Owing to their peculiar habits pine mice are not so well known as are meadow mice. Their natural habitat is the forest, although they are by no means restricted to pine woods or forested areas. While often inhabiting pine woods and the edges of adjacent fields, they live also in forests and copses of deciduous trees, usually on uplands.

"The life of pine mice is largely spent in underground tunnels, which so closely resemble those of the mole that generally they are mistaken for the work of that animal. The ridges of loose soil over the tunnel are exactly like those thrown up by the mole, but the inner diameter of mouse tunnels is less. Some of these burrows are utilized as nesting places. Nests are built also at the surface of the ground, under fallen logs, brush heaps, flat stones, fences, or other shelter. The number of young at birth evidently averages less than is usual in the genus Microtus.

"From their homes in woods and thickets pine mice invade fields, orchards, nurseries, dooryards, and gardens, passing always through underground runways. Living in concealment, neither their presence nor the injury they inflict is suspected until the latter is past remedy. Bulbs, planted hopefully in autumn, appear not at all in the spring, or only in the shape of sickly plants, whose life substance has been gnawed away. Nursery and orchard trees here and there put forth no leaves, and an examination of the roots discloses the nature of the damage.

"Potatoes, sweet potatoes, carrots, beets, and other vegetables are eaten by pine mice, both while growing and when stored in pits or lying in piles in the field or garden. Potatoes partly matured or 

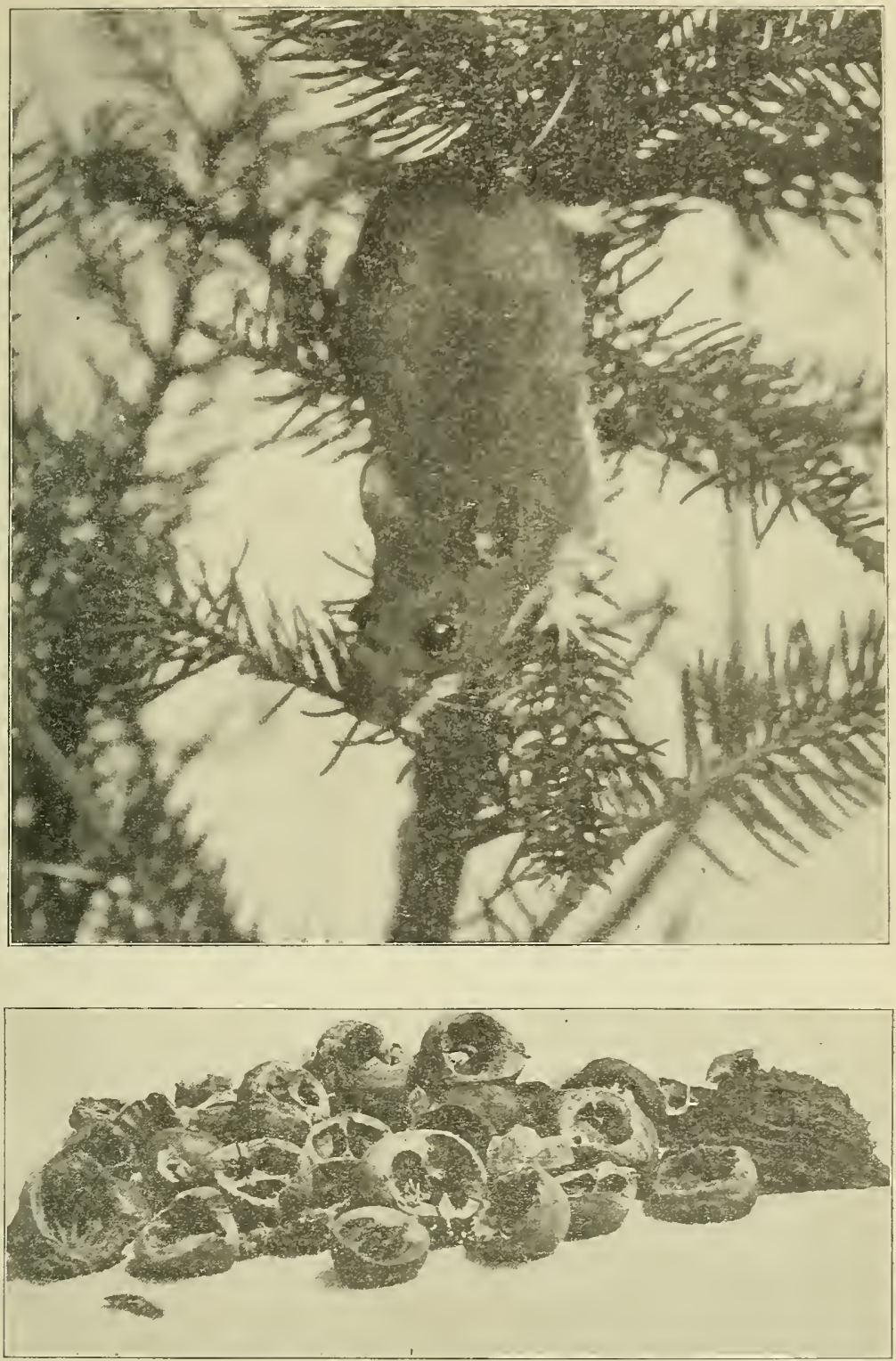

White-footed mouse and its favorite food. The nut shells were found about the nest of a white-footed mouse in a crevice of a large rock in the woods. 


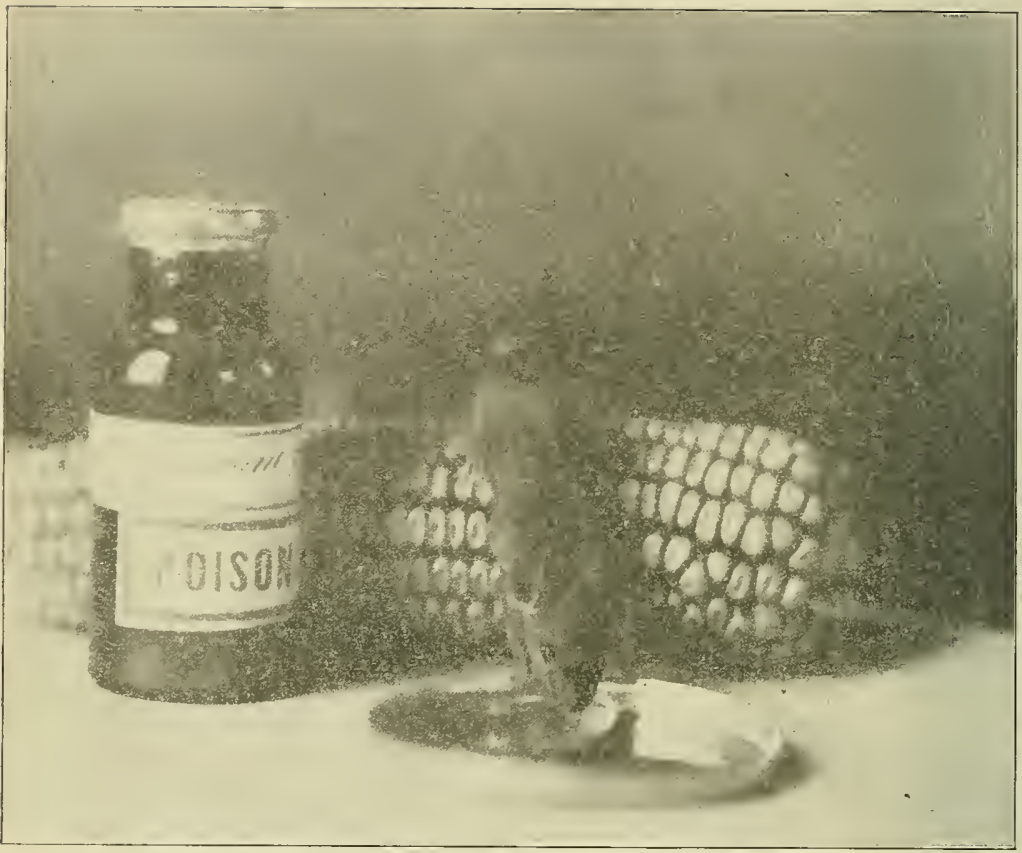

The common House Mouse, Mus musculus.

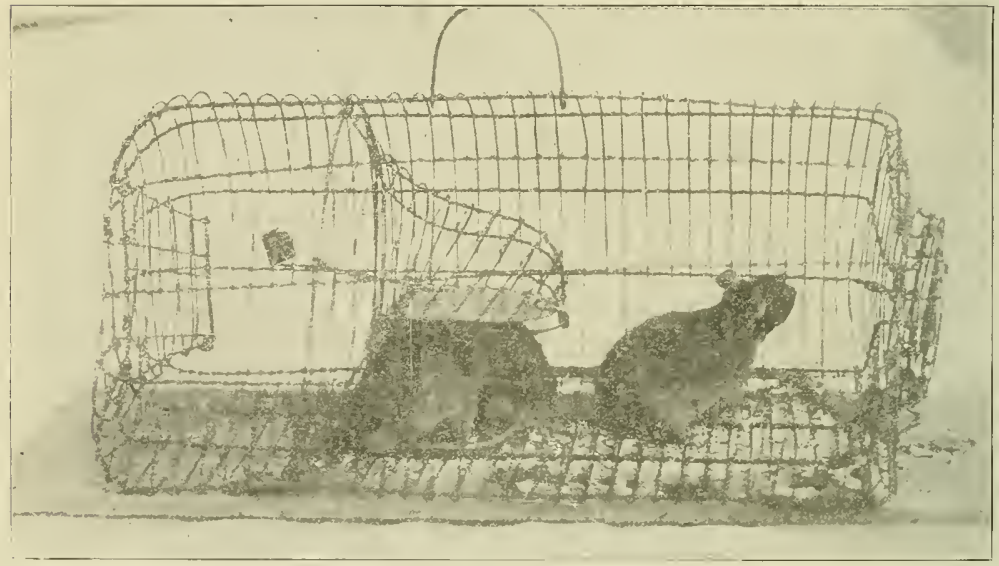

Three young rats, after having been fed for forty days on "Azoa," a new kind of rat and mouse exterminator. 
left long in the ground after maturity are eaten, and the injury is attributed to moles, because tunnels supposed to be the work of moles lead to the place of damage. I have investigated numerous cases of such injury and have invariably found either that the tunnels were made by pine mice, or, if mole tunnels, that they were frequented by mice. Traps set in the tunnels at the potato hills captured pine mice, and the starchy material found in the stomachs of those caught proved that they, and not moles, had been eating the potatoes."

\section{REPRESSION OF FIELD MICE.}

\section{TRAPPING.}

"Trapping is a simple way to destroy field mice, butt it is seldom resorted to because few people have patience to follow it up persistently and to look after the necessary large number of traps. When field mice are abundant it is éssential to use many traps and to continue trapping for several weeks. Equipped with a hundred or more effective traps, a good trapper should be able to make decided inroads upon the numbers of the pests, if not to practically exterminate them over a limited area.

"Trapping has special advantages for small areas, such as lawns, gardens, and vegetable or nursery pits and packing houses, where a limited number of mice are present, and wherever, for any reason, there are objections to the laying out of poison.

\section{PoIsONING.}

"All things considered, strychnine is the most satisfactory poison for field mice. Although a very deadly substance, it is less dangerous to handle than either phosphorus or potassium cyanide. Its extreme bitterness renders it less liable to be mistaken for a harmless drug. Nevertheless, every precaution should be taken in handling it. The strychnine salt most used commercially is strychnia sulphate. This is the best for poisoning purposes, since it is soluble in boiling water, while the alkaloid requires the presence of an acid for its solution. To disguise the bitterness of the poison when employed for rodents, sugar is used, or the strychnine may be mixed with its own bulk of commercial saccharine.

"For poisoning field mice various baits may be recommended, such as wheat, oatmeal, and corn, among the grains, and seeds of various plants, as the tomato, dandelion, sunflower, and others. The bait should be soaked over night in a poisoned sirup, which may be prepared as follows: 
"Dissolve an ounce of strychnia sulphate in a pint of boiling water; add a pint of thick sugar sirup and stir thoroughly. The prepared sirup may be scented by a few drops of oil of anise or rhodium, but this is not essential. A half ounce of borax is said to keep the mixture from molding.

"The above quantity (a quart) of sirup is enough to poison a half bushel of wheat or corn, but smaller proportional quantities of grain and sirup may be mixed as needed. If after thorough mixing the solution is not sufficient to wet all the grain, add a little water. After standing over night, if the grain is too wet, a little dry corn meal will take up the excess of moisture. If oatmeal is used as a bait, when the mass is wet throughout with the sirup, it may be used immediately.

"Because of the danger of destroying native birds, such as quail, sparrows, and others, the poisoned bait should not be placed in exposed situations, but under shelters which will admit mice but exclude birds. Wide boards lying upon thin cross pieces of wood are excellent for the purpose. For pine mice baits may be placed in the underground tunnels without endangering birds. For other mice pieces of drain tile about one and a half inches in diameter may be laid along the trails, and the baits inserted into the tiles with a long knife or spoon. Tiles are recommended by the French Minister of Agriculture, but old tin cans with flattened ends or small openings are excellent substitutes.

"In winter the following plan is especially recommended for orchards and nurseries:

"Cut small twigs from branches of apple trees (suckers are excellent for this purpose) and either dip them in the strychnine sirup or apply the sirup to them with a brush. Scatter the poisoned twigs near the trees to be protected. This plan is excellent for either field mice or rabbits, and it entirely obviates the danger of poisoning birds or domestic animals." (Bulletin No. 31, Biological Survey, 1907.)

Various other methods of repressing field mice are discussed in the bulletin just quoted, together with a general exposition of the whole subject.

It is quite likely, that of the two species of mice described, the pine mice, where abundant, are much more harmful than the meadow mice. Where field mice are troublesome, however, it is not always an easy matter to determine which of the two species may be responsible for the damage done. The meadow mice are known to subsist largely on useless, wild plants and 
weed seeds. They also furnish food for a great many rapacious birds and mammals, such as hawks, owls, foxes, raccoons, opossums, skunks, weasels and minks, which without the mice would be forced to turn their attention more largely to useful song and game birds or domestic fowls. So close an observer of wild animals as Samuel N. Rhoads believes that no sufficient grounds have yet been found to justify the destruction of the common meadow mouse, but that the pine mice deserve to be killed.

\section{INSECT FOOD OF MICE.}

There may usually be found scattered about the nests and along the trails of meadow mice a great many legs and wings of grasshoppers, large beetles, and other insects. It is probable that some of these insect remnants are the discarded portions left by shrews, but I believe that meadow mice may also be responsible for a part of them. In captivity they will pounce upon, and greedily devour, almost any kind of insect that may be placed in their cages.

One meadow mouse that I kept in a cage ate, from October 24th, 4 p. m., to October 26th, 9 a. m., a periol of 40 hours, 68 large white grubs, two crickets, nine large grasshoppers, and 46 grams of potato. The insects eaten weighed 49 grams. More potatoes than the mouse could eat were kept in the cage during the feeding test, but all the insects that were supplied were eaten, and the mouse seemed to prefer them to the potato.

This experiment was not carried on for a long enough time to make it of much value, but the results are given for what they are worth, as illustrating the fondness of mice for insect food.

\section{"AZOA. (RAT VIRUS)."}

There has lately been placed on the market, by one of the leading chemical manufacturing firms of the country, a new kind of rat and mouse exterminator, called "Azoa (Rat Virus)." The material is described by the manufacturers as follows: 
"Azoa (Rat Virus) is a disease-producing virus that when eaten by a rat or a mouse, infects with a disease that kills in from eight to fourteen days. Owing to the cannibalistic nature of these rodents, the disease is transmitted from one to another until all the rats and mice in a particular locality have been destroyed."

A test was made of this new remedy on rats and mice, both in captivity and at large, but without any apparent discomfort to the animals. One of these tests may be described as follows :

A supply of the "Azoa" was obtained direct from the laboratories of the manufacturers. On July 27th, 1907, while the material was yet fresh, three young Norway rats were caught, and kept confined, in a large, wire rat-trap. Beginning with the date given and for a period of forty days thereafter the "Azoa" was fed to the rats at intervals of a few days until ten seventy-five-cent bottles had been consumed. The rats ate the cracked grain with which the virus was mixed very readily, and other food was denied them each time the "Azoa" was given until every particle was eaten. At the end of the forty days the rats were still apparently in a healthy condition, and were removed from the trap and killed with a club.

OTHER MICE THAT HAVE BEEN, OR MAY BE, FOUND IN WEST VIRGINIA.

\section{SHORT-TAILED MICE.}

Cooper's Lemming, Synaptomys cooperi Baird.

A northern species of short-tailed mouse that follows the Alleghanies south as far as North Carolina. Is likely to occur in swampy places in the higher parts of the State.

Red-backed Mouse, Evotomys gapperi (Vigors).

A northern species that extends its range into West Virginia. Smaller than the common meadow mouse. Frequents swamps and evergreen forests. 


\section{LONG-TAILED MICE.}

Ifouse Mouse, Mus musculus Linnaeus.

The common long-tailed, gray mouse of dwelling houses and barns. Introduced into America many years ago from thz Eastern Continent. A widely distributed and well-known pest.

White-footed Mouse, Peromyscus leucopus (Rafinesque).

Also called Deer Mouse and Wood Mouse. An attractive and common little mouse found in woody places throughout the state, except in the Canadian zone. Feeds on nuts and seeds an 3 is also fond of insect and other animal food.

Canadian White-footed Mouse, Peromyscus canadensis (Miller).

Found in the forests of our ligher mountain regions. Collected by A. B. Brooks in the mountains about Hánging Rock, in Greenbrier, Nicholas and Webster Counties, in 1904. Collected at Cheat Bridge, Pocahontas County, in 1906.

Surber's Harvest Mouse, Reithrodontomys lecontii impiger Bangs.

The smallest mouse found in West Virginia. The first specimens known of this species were collected by Mr. Thaddeus Surber at White Sulphur Springs, W. Va.

The Meadow Jumping Mouse Zapus hudsonius Miller.

A handsome little mouse with an extremely long tail, sometimes found in meadows and other cleared lands of West Virginia. I found a family of five or six, living in a shock of cornfodder in Upshur County several years ago. Edw. and Wm. Behrens report that this mouse was quite common in a meadow at Sherrard, Marshall County, in the summer of 1907. This species, like the following, hibernates in cold weather.

Woodland Jumping Mouse, Zapus insignis Miller.

A beautiful and rare little mouse that is sometimes found along the streams of deep woods in West Virginia. I have seen but two live mice of this species. One was in the mountains near Cleveland, Webster County, in the summer of 1894; the other I shot on April 27th, 1906, at French Creek, W. Va. 
